Portland State University

PDXScholar

$1-1-2011$

\title{
A Study of Compensation for Face-Threatening Acts in Service Encounters in Japan and the United States
}

Miki Murakami

Portland State University

Follow this and additional works at: https://pdxscholar.library.pdx.edu/open_access_etds

Let us know how access to this document benefits you.

\section{Recommended Citation}

Murakami, Miki, "A Study of Compensation for Face-Threatening Acts in Service Encounters in Japan and the United States" (2011). Dissertations and Theses. Paper 381.

https://doi.org/10.15760/etd.381

This Thesis is brought to you for free and open access. It has been accepted for inclusion in Dissertations and Theses by an authorized administrator of PDXScholar. Please contact us if we can make this document more accessible: pdxscholar@pdx.edu. 
A Study of Compensation for Face-Threatening Acts in Service Encounters in Japan and the United States

by

Miki Murakami

A thesis submitted in partial fulfillment of the requirements for the degree of

\author{
Master of Arts \\ in \\ Japanese
}

Thesis Committee:

Suwako Watanabe, Chair

Patricia J. Wetzel

Laurence Kominz

Portland State University

(C)2011 


\begin{abstract}
This study examines how people compensate for their inability to accommodate the needs of others in service encounters. Being unable to meet others' needs violates the positive face of one of the participants in a discourse. Many previous studies on speech acts demonstrate how people control their utterances to avoid causing a face-threatening act. However, the language behavior that follows a face-threatening act has not yet received much focus.

This paper looks at two different kinds of data in Japan and the United State (hereafter "U.S.”) using two different approaches: observation and role-play. In the first, the observational phase, the author acted as a customer in several convenience stores in Japan and asked for an item that they did not carry. In the U.S., a native English speaker interacted with the salesclerk as the customer. (No recording device was used in either situation.) All exchanges were immediately recorded by hand and later coded by semantic formulas. In the second, the role-play phase, native speakers were asked to roleplay a parallel situation in which they acted as a salesclerk and had to react to not being able to satisfy customers' requests. The results demonstrate that Japanese sales clerks compensate in the face of their inability to meet another's need (they avoid a direct facethreatening act) whereas most U.S. sales clerks do not attempt to compensate for their inability. These behaviors correlate with social expectations of the participants within both respective service encounters. Moreover, the results also suggest a re-thinking of speech acts and emphasize the importance of natural data.
\end{abstract}




\section{Dedication}

To my parents, Susumu Murakami and Hisako Murakami, and my brother Takaya Murakami, for their unfailing support and encouragement 


\section{Acknowledgement}

I would like to express my deep appreciation to the following people:

My thesis advisor, Dr. Suwako Watanabe, for the inspiration to study sociolinguistics, and for her scrupulous guidance, thoughtful support and continuous encouragement; Dr. Patricia J. Wetzel for her knowledge of linguistics, consideration, generosity in allowing me to teach Japanese at PSU, and various and constant support during my time in Portland;

Dr. Laurence Kominz for his knowledge of Japanese literature and his willingness to spend his valuable time reviewing my thesis and providing me with thoughtful comments and insights;

Thomas Mason for allowing me to participate in the ALLEX program and for training me as a Japanese teaching assistant;

Irene Alderman for providing me with my first opportunity to teach Japanese in the U.S.; Lisa Mick Shimizu for enthusiastically assisting me with data collection for this study, and for her thoughtful support and kind friendship;

Greg Van Buren for kindly spending his precious time in the data collection for this study, considerations and kind friendship;

Christopher Alderman, Eric Christensen, John Delli Carpini, and Robert Hegwood for helping me so patiently and kindly with my writing; Kanako Yao, Hiroko Katsuta, Mami Harano, and Elizabeth Dillard for their thoughtful support, patient encouragement and kind friendship;

All anonymous participants in this study for devoting their precious time. 
Table of Contents

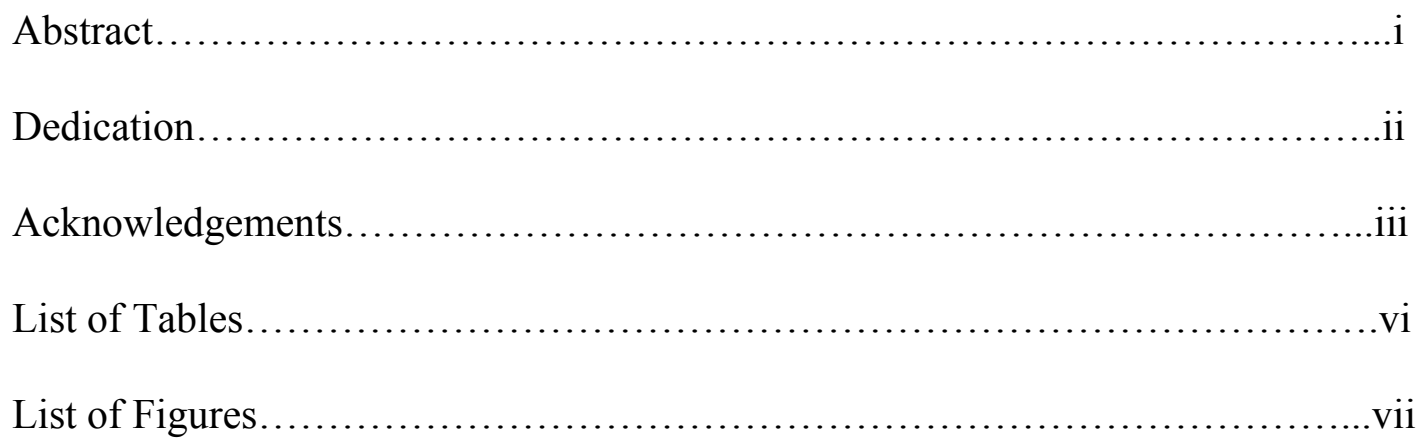

Chapter 1

Introduction........................................................

Chapter 2

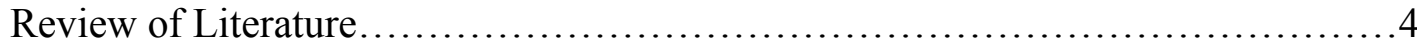

Chapter 3

Methodology............................................................ 19

Chapter 4

Results............................................................ 40

Chapter 5

Discussion........................................................66

Chapter6

Conclusion............................................................ 92

References........................................................ 95

Appendices

A. Natural speech sample from convenience stores coded by semantic formulas in Japan and the U.S...................97

B. Transcript of role-play coded by semantic formulas in Japan and the U.S....................................... 102 


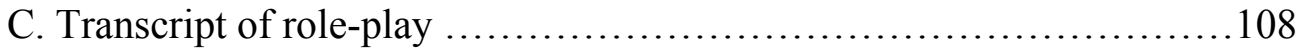

D. Analysis of face-threatening acts in natural speech samples from convenience stores..........................................113

E. Informed Consent (English).................................... 122

F. Informed Consent (Japanese) .....................................124

G. Situation Card for oral role-play (English).........................126

H. Situation Card for oral role-play (Japanese).......................127 
List of Tables

Table 1: The list of semantic formulas for coding............................23

Table 2: Comparison of coding by semantic formulas between a graduate student and a researcher..........................28

Table 3: The frequency of semantic formulas.............................40

Table 4: The frequency of spontaneously providing alternative items in Japan and the U.S..........................43

Table 5: Semantic formulas following the "customer's insisting on the necessity of the item" ............................45

Table 6: Semantic formulas following after the "customer's inquiry about other stores".

Table 7: The number of sales clerks who used a modal expression in Japan and the U.S

Table 8: The number of sales clerks who used silence in Japan and the U.S.

Table 9: The occurrence of "providing information" following "customer's insisting on the necessity of the item" or "customer's inquiry about other stores" 


\section{List of Figures}

Figure 1: Frequency of semantic formulas................................ 41

Figure 2: The length of exchanges in Japan.............................58

Figure 3: The length of exchanges in the U.S...........................58 


\section{CHAPTER 1}

\section{Introduction}

The purpose of this study is to investigate linguistic tactics people use to compensate for their inability to accommodate others' needs in service encounters both in Japan and the United State (hereafter "U.S."). When in a situation where we cannot meet others' needs, cultural conventions require us to express regret. In this study, I examine types of linguistic behaviors that occur in the process of compensation in Japan and the U.S. More specifically, I investigate a specific scenario in which a customer goes to a convenience store and asks for blue cheese, which the convenience store does not sell or carry. A typical exchange occurred as follows:

Customer: Do you have blue cheese here?

Sales clerk: No, we don't.

The sales clerk is involved in a situation in which he/she cannot meet the customer's needs. However, he/she still has to inform the customer that the store does not have what the customer wants. This conversation exhibits the inability of a sales clerk to meet the customer's needs; the "faces" of both customer and sales clerk are threatened simultaneously.

According to Brown and Levinson (1987), every person has two different kinds of face: negative face and positive face. They define negative face as "the want of every 'competent adult member' that his action be unimpeded by others, while positive face is defined as "the want of every member that his wants be desirable to at least some others" (p. 62). In other words, negative face is the desire to be able to behave as one wants, 
whereas positive face is the desire for one's behavior to be acceptable or liked by others. Therefore, in the service encounter that is studied herein, when a customer inquires about what he/she wants to buy and a store does not carry it, the response of the sales clerk threatens the customer's negative face because the customer cannot buy (in this example) blue cheese. That is, his/her desire to buy the product is impeded by the sales clerk. Simultaneously, the customer also threatens the sales clerk's positive face because by saying "no" to a customer, the sales clerk may be perceived as an undesirable person. However, it is inevitable that the sales clerk will say so, unless he/she is willing to risk telling a lie.

In the field of linguistics, the speech act theory, as originally advocated by Austin (1962) and further developed by Searle (1969), describes strategies of language use when we intend to achieve a certain purpose such as a request, refusal or apology. In the process of achieving this purpose, the speaker's intention is sometimes explicitly demonstrated through language, or in other cases, it is implicitly embedded in the discourse. Austin (1962) theorized the notion of the speech act, and later Searle (1969) proposed direct and indirect speech acts.

Previous studies on speech acts demonstrate that speakers' utterances are carefully chosen to avoid face-threatening acts, a term coined by Brown and Levinson (1987). However, speech acts that originate from a situation where the speaker is forced to perpetrate a face-threatening act have not received much attention before now. This study aims to uncover the sequence of a speaker's compensation for a face-threatening act by examining the particular situation of service encounters. Generally speaking, one 
cannot avoid perpetrating face-threatening acts. We all do so when refusing another's invitation, asking for another's help, and so forth. However, in order to empirically show how people compensate for their inability to meet others' needs, the circumstances must be such that a researcher can easily initiate a face-threatening act and collect data on a systematic basis. Furthermore, the situation that I create is likely to occur in our daily life - thus it lends itself to data reliability. Hence, the context of the service encounter is ideal for this study.

Additionally, since the politeness theory accounts for linguistic conventions or norms, I examined the same situation in different countries, Japan and the U.S. In my experience, sales clerks in Japan tend to use very polite expressions and to apologize before anything else when they cannot accommodate customers' needs, such as uncommon clothing sizes in a department store. Moreover, in Japan, when a customer leaves, he/she frequently says, "Mata onegai simasu" ("please come again"). In the U.S., on the other hand, it is rare to hear a sales clerk apologize even when the sales clerk cannot provide the desired product. According to my findings, a U.S. sales clerk tends to provide information such as online shopping options, suggestions about chain stores, etc. A previous study by Tsuda (1984) also demonstrates that Japanese people are concerned with maintaining harmony, and this influences their choice of language. Thus, examining the same speech act in different countries also allows us to discover the differences of language use in the communicative situation. 


\section{CHAPTER 2}

\section{Review of Literature}

\section{Theoretical Framework}

- Speech act theory

Austin (1962) observed that "to say something is to do something; or in which by saying or in saying something we are doing something” (p. 101). In other words, we achieve our purpose by using language, and whenever we utter something, we convey the purpose explicitly or implicitly. He also categorized the performance of possible acts into three groups: locutionary acts, illocutionary acts, and perlocutionary acts. He defined locutionary acts as the utterance of a sentence with a referential meaning; an illocutionary act as an utterance which has certain conventional force, such as a request, apology, promise, or warning; and a perlocutionary act as an utterance which is not necessarily conventional but achieves a discourse-level purpose, such as convincing, persuading, deterring, surprising, or misleading.

Searle (1969) further developed the concept of speech acts, dividing them into direct speech acts and indirect speech acts. He states:

The speech act or acts performed in the utterance of a sentence are in general a function of the meaning of the sentence. The meaning of a sentence does not in all cases uniquely determine what speech act is performed in a given utterance of the sentence, for a speaker may mean more than what he actually says, but it is always in principle possible for him to say exactly what he means (p. 18).

The presentation of intention itself is not necessarily always clear to an addressee because the speaker sometimes implies or indirectly expresses his/her intention by means of manipulating language. Yet speakers can achieve their purpose through language. 
- Cooperative Principles

Grice (1975) proposed the concepts of "conversational implicature" and “cooperative principle" (p. 45). According to Grice (1975), the term "implicature" refers to speakers' implications in their utterances in pursuit of specific speech acts. He proposed the concept of "conversational implicature" defined as, "a certain subclass of nonconventional implicature" (p. 45). In other words, when we interact with others, we control our language use; we convey the message explicitly, or we embed actual intention into our discourse and imply the message. Grice (1975) also explains the general principle of talk exchanges. He mentions, "our talk exchanges do not normally consist of a succession of disconnected remarks, and would not be rational if they did. They are characteristically, to some degree at least, cooperative efforts; and each participant recognizes in them to some extent, a common purpose or set of purposes, or at least a mutually accepted direction" (1975, p. 45). Namely, the speaker could achieve his/her illocutionary force without problem because the participants of the conversation, the speaker and addressee, intend to perceive each other's intention and interpret correctly and respond to the other appropriately. Even if the utterances implicitly convey the speaker's intention, the speaker's want can be achieved by means of the addressee's cooperative effort. Grice (1975) called the principles that underlie smooth communication "cooperative principles," and divided them into four categories: quantity, quality, relation, and manner. The definition of each is as follows (1975, p. 45):

Quantity:

1. Make your contribution as informative as is required. (for the current purpose of the exchange) 
2. Do not make your contribution more informative than required.

Quality:

1. Do not say what you believe to be false.

2. Do not say that for which you lack adequate evidence.

Relation:

Be relevant.

Manner:

1. Avoid obscurity.

2. Avoid ambiguity.

3. Be brief (avoid unnecessary prolixity).

4. Be orderly.

Grice (1975) observes that participants of a conversation achieve the smooth conversation unconsciously or consciously. Moreover, the use of "cooperative principles" helps reveal the underlying expectations of participants. Accurate interpretations of a speaker's expectation allow an addressee to choose relevant maxims. However, an addressee does not know whether or not his/her interpretation and the use of a maxim are appropriate until the speaker responds to his/her utterance. Both speaker and addressee achieve his/her purpose by means of negotiating intention and cooperative effort one another.

- Politeness theory

Brown and Levinson (1987) advocated that the contemporary notion of “politeness" is based on Goffman's (2006) notions of the line and face. According to Goffman (2006), all humans experience life by dealing with social interaction which can be face-to-face, or be arbitrated by others (p. 299). A person expresses his/her view or evaluation of participants or him/herself verbally or nonverbally in the interaction. 
Goffman (2006) terms the pattern of such verbal or nonverbal act as a "line" (p. 299). In social interaction, a speaker effectively acts out a line. Simultaneously, other participants create the speaker's impression through interpreting the speaker's line. Therefore, the speaker demonstrates a line by means of considering the way that maximizes the possibility of giving the participants a good impression of him/her when he/she responds to other participants. This correlates to Goffman's face (2006, p. 299). According to Goffman (2006), face refers to "the positive social value a person effectively claims for himself by the line others assume he has taken during a particular contact"' (p. 299). Goffman (2006) also defines face as "an image of self delineated in terms of approved social attributes - albeit an image that others may share, as when a person makes a good showing for his profession or religion by making a good showing for himself' (p. 299). Thus, in face-to-face interaction, there is the tendency to deliberately generate a line that displays oneself positively by monitoring oneself or evaluating other participants.

Brown and Levinson's concept of positive face and negative face originates in Goffman's notion of face. They defined positive face as the desire for the approval of others, while negative face refers to the desire that our activities be unimpeded. An act that violates either kind of face is called a face-threatening act (FTA). An act oriented toward satisfying another's positive face is positive politeness, and toward negative face is negative politeness $(1987$, p. 316). It is ideal to interact with others without causing any FTA; however, it is inevitable in face-to-face interaction because interaction itself can be an FTA in a sense. When a speaker causes an FTA, the speaker uses strategies to mediate 
the act, or the speaker intends to minimize face damage even in the process of causing an FTA.

Brown and Levinson (1987) more specifically explain the strategies of performing an FTA. There are two methods of performing an FTA, which is "on-record" and "offrecord" (p. 69). "On-record" represents conveying the message directly, whereas "offrecord" exhibits the speaker's intention by implication or contextual hint. For instance, when a speaker clearly refuses an invitation for a party from an addressee, it is an onrecord FTA. Conversely, when a speaker responds by saying "Um, I don't know if I can make it" to the addressee, it is an off-record FTA because the speaker does not explicitly say "no;" instead, he/she implies the possibility of his/her not coming to a party. Afterwards, if the speaker verbally mediates the FTA, the act is considered to be a redressive action. There is also the case that an interaction terminates without a redressive action. Furthermore, when a speaker exhibits a redressive action, there are some actions that aim for positive politeness or negative politeness. Positive politeness is approachbased, and negative politeness is avoidance-based. For example, when a speaker wishes to make his/her act is effective through positive politeness, the speaker intends to admire the addressee or emphasizes the benefit because he/she wants to be liked. On the other hand, when the speaker wants to act to satisfy the addressee's negative face, he/she intends not to interfere with the addressee's want; thus, he/she will apologize for the FTA, or use hedging expressions. 
- Semantic formulas

In previous studies, semantic formulas have been used to code speech acts in roleplay such as the cross-cultural speech act realization project conducted by Blum-Kulka, House, and Kasper (1989). Bardovi-Harlig (2001) explains that "semantic formulas represent the means by which a particular speech act is accomplished in terms of the primary content of an utterance" (p. 16). In other words, semantic formulas are formulas that represent language behaviors capable of facilitating communicative acts, such as expressions of apology and gratitude. One semantic formula can be used for several different utterances. For instance, in an apology, one may say "Sorry," but the other might say "Excuse me." Therefore, when a communicative act is coded by semantic formulas, it is impossible to know what the speaker actually uttered; yet, by means of examining the sequence of semantic formulas, it becomes possible to discover the strategy of speech acts. Thus, I used semantic formulas as a tool of coding for a data collection of this study. I created a list of semantic formulas by referring to previous studies and accommodating them for the purpose of this study (see the methodological section for the list of semantic formulas).

- Institutional Talk

Drew and Heritage (1992) define institutional interaction as "the principal means through which the lay person pursues various practical goals and the central medium through which the daily working activities of many professionals and organizational representatives are conducted" (1992, p. 3). They term the talk that occurs in such 
settings as institutional talk. Drew and Heritage (1992) also propose the conditions of institutional talk as follows (p. 22):

1. Institutional interaction involves an orientation by at least one of the participants to some core goal, task or identity (or set of them) conventionally associated with the institution in question. In short, institutional talk is normally informed by goal orientations of a relatively restricted conventional form.

2. Institutional interaction may often involve special and particular constraints on what one or both of the participants will treat as allowable contributions to the business at hand.

3. Institutional talk may be associated with inferential frameworks and procedures that are particular to specific institutional contexts.

Taking the conditions above into account, participants of institutional interaction must have certain goals to achieve and contribute to the institution in which they are involved. Participants' utterances are also constrained by their role in the institution. The role in which participants are engaged requires participants to control their utterances based on the conventions of their institution. For example, hospitals are a locus of an institutional interaction because participants such as doctors, nurses, and patients have their own goals to achieve. A doctor's role is providing a patient with care. A nurse's role is to care for patients and also support a doctor. A patient's role is to have his/her illness treated. In terms of the hospital language, doctors and nurses change their speech style depending on the addressee's role (Drew \& Heritage, 1992). For instance, a doctor uses medical terminology when he/she informs his/her diagnosis or direction of treatments to a nurse. However, the doctor explains to the patient or his/her family by simplifying medical terms so that the doctor ensures that the patient and his/her family understand patient's condition. This is because the doctor assumes that the nurse expects him/her to 
provide his/her diagnosis and instruction to take care of patient, while the patient and his/her family expects him to provide a detailed explanation in intelligible language. Expectations sometimes vary among cultures even in similar institutions because each differs in terms of cultural conventions. Considering the definition of institutional interaction proposed by Drew and Herritage (1992), the service encounter is an institutional interaction, and the talk occurring in a service encounter demonstrates characteristics of institutional talk. This also affects the speech act; in this study, the compensation for a face-threatening act.

- Service encounters

There is a body of prior research related to service encounters. Labov's (1966) early work examined language variation, specifically the production of English sounds of $/ \mathrm{r} /$ in three different ranks of department stores in New York City. He discovered that the pronunciation of specific English /r/ can be correlated with people's norms of formality. In other words, the choice of language differs based on generation, gender, and/or social rank in the community.

Tsuda (1984) compared sales talk between Japanese and U.S. speakers. She found that U.S. salespersons have more freedom of expression, whereas Japanese salesperson's language is more restricted by the expectation of a customer and their role as salespersons. Thus, some discourses in Japanese involve the sales person's use of honorific forms towards a customer. Japanese salespersons also display a tendency to create mutual harmony with a customer by language in order to avoid direct confrontation. 
Of greatest relevance to this study is the work of Merritt (1976) who examined patterns of discourse between sales clerks and customers in stores in the U.S. Discourse by a speaker creates a slot, which is meant to be filled by the hearer. A slot is the transition space between a speaker's utterance and a hearer's utterance in a conversation flow. When a speaker makes an utterance, a slot is then generated. The hearer intends to fill the slot, i.e., to respond to the speaker. The hearer's response fills that slot. In the process of the hearer's determination of how to fill the slot, he/she considers his/her knowledge of this world and how the filler will be interpreted by the speaker. Merritt (1976) analyzed the interaction between sales clerks and customers during service encounters, an ideal situation to observe frequent occurrences of slots at a discourse level. It also provided a situation that minimized the variation of interpretation due to the participants' varying knowledge of the world. She recorded over 1000 natural conversations exchanged between sales clerks and customers in stores at a university. She discovered that even though the hearer's answer to the speaker's question did not answer the question directly, the participants' communication still developed smoothly and the speaker was able to achieve his/her purpose of coming to the store. In one instance, when the speaker asked a question to the hearer, the hearer replied with a question, not an answer. Although it is grammatically illogical to answer to the speaker's question with a question, the participants were still able to proceed with their conversation without any trouble. However, the participants were still able to proceed with their conversation without any trouble. The following example has been taken from Merritt's data (1976, p. 339): 
Q1 C: Do you have coffee to go?

Q2 S: Cream or sugar? (starts to pour coffee)

C: Cream only.

S: O.K. (putting cream in)

The first question, "Do you have coffee to go?" invokes a contextual presupposition and the hearer, i.e., the sales clerk, interpreted that this customer wanted coffee; therefore, the sales clerk omitted the direct answer to the question, which might possibly have consisted of "yes" or "no." Instead of the appropriate grammatical response, the hearer uttered, “Cream or sugar?” (p. 339). Even though the first question and the response are not grammatically coherent, they are contextually appropriate; thus, no communication breakdown occurred.

Merritt (1976) discovered the system of coherence and pragmatic interpretation within such discourses. She discovered that illocutionary force, i.e., the request of a customer, is interpreted in two different ways by a sales clerk: as the purpose of obtaining the information and as receiving actual service. For example, asking whether the store carries the item that a customer wants is a request for information, while buying goods from the store is receiving actual service.

According to Merritt (1976), from the speaker's viewpoint, the notion of coherence is constructed through a sequence of sentences, regardless of whether complete sentences are used or not. Therefore, each sentence does not occur randomly; rather the speaker selects it based on the relevance to the preceding utterance. On the other hand, the hearer simultaneously creates the notion of relevance. The hearer attempts to understand and analyze the speaker's sentence in order to make his/her reply relevant to 
the speaker's earlier sentence (Merritt, 1976, p. 316-317). Thus, Merritt (1976) explained that "each sentence in a coherent discourse can be assumed to be interpretable, and can be examined for the achievement of interpretability" (p. 316-317). Since the discourse occurs in social interactions, the speaker and the hearer of the discourse interpret each other's sentences based on their knowledge of the world, which is called pragmatic interpretation. Especially in a dialogue, the speaker's utterance creates a slot that the hearer simultaneously fills. The meaning of each slot is contingent upon the hearer's interpretation of each newly created slot.

Merritt analyzed a specific set of utterances from the aspect of adjacency pairs, which was originally proposed by Sacks and Schegloff (2006), in order to find out what kind of mechanism of coherence and pragmatic interpretation was embedded within discourses as well as to discover a deeper understanding of how the two interacted with one another. According to Sacks and Schegloff (2006), an adjacency pair is identified by the following features (p. 264):

(1) two utterance length, (2) adjacent positioning of component utterances, (3) different speakers producing each utterance, (4) relative ordering of parts (i.e., first pair parts precede second pair parts), and (5) discriminative relations (i.e., the pair type of which a first pair part is a member is relevant to the selection among second pair parts).

Merritt (1976) identified the relationship between question and answer as an adjacency pair consisting of conditional relevance as an integral component within each occurrence. This concept was first proposed by Sacks and Schegloff (1972). Merritt (1976) concludes that the adjacency pair is "a unit of verbal behavior that is larger than the sentence or utterance and smaller than (or equal to) the discourse. The adjacency pair 
is, of course, not a purely linguistic unit. It may also be constructed as a unit of interaction" (p. 328). In other words, the second utterance is usually predictable from the first utterance given in an adjacency pair. The hearer has an expectation of what kind of utterance will come next. This explains why the occurrence of grammatically incoherent adjacency pairs does not truly impede comprehension between participants. Speakers continually apply their expectations when interpreting one another's utterances.

Merritt (1976) discovered that there are four characteristics that define the relationship between question-answer pair, this includes the following: chaining, embedding, coupling, and elliptical coupling (p. 353). She especially focused upon the occurrence of elliptical coupling. In her data, several subjects demonstrated questionquestion adjacency pairs, which she categorized as question-answer exchanges with the concept of elliptical coupling. She explained that "elliptical coupling describes those exchanges in which the first turn instates the conditional relevance of certain type of reply (here, answer), and the second turn contains no reply of that type as such, but after which conditional relevance has been satisfied" (Merritt, 1976, p. 343). Even though there is no grammatical connection between the first question and the second question, there still must exist some unspoken ideas that the hearer assumes the speaker implied when the first utterance was uttered in order to make an appropriate response. Merritt (1976) discovered that there are three conceptual notions that affect the system of coherent and pragmatic interpretation. These include the following: the rule of maximal appropriateness, contextual presuppositions, and a response that provides an answer (p. 346). In general, the speaker's utterance is supposed to be appropriate; in other words, the 
speaker must utter something reasonable. Even from the first utterance within a discourse, there is a reason why the utterance occurs. Moreover, the hearer analyzes the first utterance for appropriateness, then interprets it, and finally utters his/her response with appropriate relevancy to the first utterance. This appropriateness is tightly related to the context in which the speaker and hearer engage. A speaker's utterance makes a hearer analyze what the speaker intended to say from the context. In other words, the first utterance of the speaker invokes the hearer to make an assumption about the context of what was said. Therefore, the hearer's reply is affected by how the hearer interprets the inferred meaning from the first utterance; Merritt (1976) defined this assumption as contextual presupposition.

Thus, in question-question sequences as seen in the earlier example, the first question and the second question are conditionally relevant because the second question will never occur without the first question. The system of coherent and pragmatic interpretation is achieved by constant conscious interpretation of contextual presupposition and appropriateness of the participants' responses to one another.

\section{$\underline{\text { Research Questions: }}$}

Q1. How do sales clerks inform a customer of his/her inability to accommodate a customer's need in Japan and the U.S.?

Q2. How do sales clerks provide alternative options or facilitate information to achieve a customer's wants to compensate for his/her inability to meet customer's need in Japan and the U.S.? 
Q3. How do sales clerks react to the second utterance of a customer to compensate for his/her inability to accommodate a customer's need in service encounters in Japan and the U.S.?

Q4. To what extent and by what means is politeness conveyed through verbal communication in Japan and the U.S. when a sales clerk compensates his/her inability in service encounters?

Q5. Does the sequence of language behaviors observed in natural settings resemble the sequence in oral role-play?

\section{Hypotheses}

The following hypotheses are formulated based on the previous studies on service encounters by Merritt (1970), the notion of cooperative principle proposed by Grice (1975), the perspective of institutional talk by Drew and Heritage (1992) and politeness theory by Brown and Levinson (1987).

H1. For the first research question, "How do sales clerks inform a customer of their inability to accommodate a customer's need in Japan and in the U.S.?" it is hypothesized that the statement of inability will occur explicitly in the US. On the other hand, in Japan, Japanese sales clerks implicitly demonstrate their inability.

H2. In terms of the second research question regarding alternative options, sales clerks in both Japan and the U.S. will spontaneously provide alternative items or information that might facilitate meeting customer's need as a compensation for their inability. Based on Grice's cooperative principles, the sales clerks will attempt to provide information relevant to fulfilling the customer's need. 
H3. Research Question 3 asks how sales clerks respond to the customer's statement of want after the initial inquiry. It is hypothesized that sales clerks in both Japan and the U.S. will provide information after the second utterance of a customer, because sales clerks attempt to cooperate with a customer to achieve his/her need due to their professional role in service encounters (Drew \& Heritage 1992). In service encounters, the primary purpose is to obtain merchandise; thus both a customer and a sales clerk should work together towards achieving the goal. However, since sales clerks cannot meet their need, they will at least try to contribute to the process of obtaining the product at least. Thus, sales clerks will react to the second utterance by providing information both in Japan and the U.S.

H4. The fourth research question examines how politeness is expressed in the process of the compensation effort. Since not being able to accommodate a customer's need is a face-threatening act, a sales clerk will generate utterances that demonstrate his/her politeness in Japan and the U.S. However, Japanese sales clerks show more politeness expressions than U.S. sales clerks because Tsuda's (1984) research shows that Japanese salespersons are concerned more about the maintenance of mutual harmony compared to U.S. salespersons.

H5. The last research question asks, "Does the sequence of language behaviors observed in natural settings resemble the sequence in oral role-play?" According to Blum-Kulka et al. (1989), the role-playing is still reliable data even though it contains some limitations. Furthermore, the order of semantic formulas in natural oral data and role-playing will be analogous. 
In addition to the hypotheses above, I hypothesize that the influences of cultural differences upon participants' utterances will be observed in this study. Many studies on speech acts demonstrate salient differences in the sequence of achieving certain acts through language in different cultures, and that attributes to different cultural norms, especially regarding politeness. Furthermore, the discourse in service encounters is categorized as one of the institutional talk. Thus, the utterances of each participant must be constrained by his/her professional role in public in some way, and the role influences participants' utterances and compensates for a face-threatening act toward the other.

Taking the research questions into account, I designed a study in which I would be able to collect empirical data on a face-threatening act and a mechanism of compensation in service encounters. 


\section{CHAPTER 3}

\section{Methodology}

This chapter describes the methodology used in this study, data collection procedure, participants, and data analysis. This study utilizes a qualitative method to investigate the verbal behaviors of compensation for causing a face-threatening act in service encounters in Japan and the U.S.

\section{$\underline{\text { Research Design }}$}

In order to examine the compensation process, it is necessary to find a situation in which violation of face is inevitable. For instance, a participant is expected by the other to be able to provide his/her want; however, the person cannot accommodate the want. By convention, the person has to put some effort into compensating for his/her inability. I assumed that the situation of service encounters was a likely situation where this actually happens, and I planned to create such a situation and observe what kind of steps were taken to compensate for the inability of accommodating another's need. More specifically, I designed a situation in which I go to a convenience store as a customer and then ask for blue cheese, a product that convenience stores rarely carry. Moreover, since I hypothesized that the process of compensation for inability would be somehow demonstrated differently in Japan and the U.S., I collected spoken data from these countries and compared the compensation process.

In addition, I collected two different kinds of spoken data by using different approaches: a natural speech sample, and open-ended oral role-play. I gathered the natural speech samples from a convenience store first. The responses of sales clerks 
during the interactions with customers were collected and coded; in order to prevent the sales clerks from becoming self-conscious, the responses were coded instead of recorded with a recording device. In addition to the natural data, I administered the recording of a role-play to complement the reliability of natural data. I simulated a situation similar to the natural speech samples that were collected. Participants played the role of a sales clerk, and I played the customer's role. I asked for blue cheese, and then the participants interacted with me in the situation, namely that their store does not carry blue cheese. All role-plays were recorded with the participants' consent.

\section{Data Collection Procedure}

- Natural speech sample

Natural speech samples were collected from the exchange between a sales clerk and a customer in a total of twenty-one convenient stores: eleven in Japan and ten in the U.S. Native speakers of each language played the customer's role. In Japan, the researcher played the role, whereas in the U.S., the researcher's acquaintance, a native speaker of English, and the researcher went together but only the researcher's acquaintance actually interacted with the sales clerk. This is because the researcher is a non-native English speaker and it was assumed that interacting with sales clerks as a nonnative English speaker might affect the sales clerks' utterances. The customer's request for blue cheese was aimed to elicit the conversation and to simultaneously put the sales clerk in a situation of not being able to accommodate the customer's need, which violates the customer's negative face. The natural speech samples in convenience stores were not recorded for two reasons. First, recording the sales clerk's speech requires receiving 
consent from each sales clerk, which is a cumbersome procedure. Second, since there is the possibility that recording makes sales clerks uncomfortable, they might intend to act differently than normal, possibly leading to unreliable data. Thus, instead of recording sales clerks' utterances, the researcher memorized the sequence of utterances by semantic formulas as a coding, such as "apology" and "reason" and wrote down the codes immediately after leaving the convenience store. Since a sales clerk did not know he/she was actually participating in the study during the interaction with the researcher, it is relevant to consider that all exchanges between the researcher and the sales clerks took place in a natural setting. The semantic formulas in this study were derived from the coding manual utilized for the Cross Cultural Speech Act Realization Project led by Blum-Kulka et al. (Bulm-Kulka et al., 1989).

- Open-ended oral role-play

For the open-ended oral role-play, participants were recruited among the researcher's acquaintances. Participants consisted of native speakers of Japanese and English who were living in their respective countries. There were six people who participated in oral role-play from each country, Japan and the U.S. The participants consisted of various genders and ages. The oral role-play was administrated in participants' native language and was recorded under the participants' consent. All exchanges were transcribed and then coded by semantic formulas as well as natural speech samples. The participants were given the situation card written in their first language. The card described the same situation as the one in which the natural oral speech sample was collected. The participants played the role of sales clerk, and the 
researcher played customer's role. The content described in the situation card was as follows:

"You are working at a convenience store here in the U.S. One day, a customer, an interviewer, comes in to the store, and asks you if the store sells/carries blue cheese; however, it does not. Please react and speak as you think and have a conversation with an interviewer, who is playing role of a customer."

After having subjects understand the context, a role-play began in the participants' native languages.

Oral role-play was administrated to record sequences and utterances produced by a sales clerk. Since natural speech samples from convenience stores were not recorded with a voice recorder, and were documented by coding only, it was impossible to examine actual phrases later on. Therefore, data from role-plays was used to supplement what the sales clerks might have actually said. Moreover, if the order of semantic formulas within each exchange in a role-play corresponds to the order of convenience stores, a role-play reinforces the findings from a natural speech sample. Furthermore, in order to ensure the reliability of coding, I asked a graduate student who is familiar with the field of linguistics and also a Japanese native speaker to code several data sets from oral role-play. The graduate student (second rater) was given the data and then coded the data by the list of semantic formulas I made. After the coding, I examined how the coding done by the second rater conformed with my coding. Afterwards, I counted the number of semantic formulas that matched my coding. The result of this examination should confirm my coding of the natural speech sample and the oral-role play. 
$\underline{\text { Semantic formula }}$

(Natural speech sample from convenience stores)

The semantic formulas in this study have been adapted from the coding manual utilized for the Cross Cultural Speech Act Realization Project led by Blum-Kulka et. al (Bulm-Kulka et. al, 1989), Byon (2004), and Taira (2008)'s study. The following is the list of semantic formulas.

\section{Table 1}

The list of semantic formulas for coding

\begin{tabular}{|c|c|}
\hline Formulae & Description and Example \\
\hline $\begin{array}{l}\text { Alerter } \\
\text { (attention-getter) }\end{array}$ & $\begin{array}{l}\text { An "'alerter" is an element whose function is to alert the hearer's } \\
\text { attention to the ensuing speech act (Blum-Kulka et al., 1989). } \\
\text { "Konnichiwa," "Irassyaimase." "Anoo" "Cyotto" "Sumimasen" } \\
\text { "Hi." "How are you?" "May I help you?" "Hey!" "Excuse me." }\end{array}$ \\
\hline $\begin{array}{l}\text { Alerter } \\
\text { (title/role) }\end{array}$ & $\begin{array}{l}\text { An "alerter" is an element whose function is to alert the hearer's } \\
\text { attention to the ensuing speech act (Blum-Kulka et al., 1989). } \\
\text { "Okyaku-sama." } \\
\text { "Sir" "Ms" }\end{array}$ \\
\hline $\begin{array}{l}\text { Repetition of } \\
\text { question/ } \\
\text { confirmation }\end{array}$ & $\begin{array}{l}\text { The speaker repeats the question from the interlocutor to make } \\
\text { sure he/she understands the interlocutor's need (Literally or by } \\
\text { paraphrase) (Murakami modified; it originates Blum-Kulka et al., } \\
\text { 1989). } \\
\text { "-arimasuka?" "-desuka?" } \\
\text { "Do you carry- here?" "Do we carry -?" }\end{array}$ \\
\hline Statement of inability & $\begin{array}{l}\text { The speaker informs the interlocutor of his/her inability to serve } \\
\text { (added in the current study). } \\
\text { "Arimasen nee" } \\
\text { "No." "No, we don't." }\end{array}$ \\
\hline Negative marker & $\begin{array}{l}\text { The speaker uses some kind of marked speech that enables the } \\
\text { requester to sense the oncoming refusal before the actual refusal } \\
\text { itself (Taira, 2008). } \\
\text { "Aaa," "Uuun", } \\
\text { "Hum." "Well." }\end{array}$ \\
\hline
\end{tabular}




\begin{tabular}{|c|c|}
\hline Avoidance & $\begin{array}{l}\text { The speaker suspends or avoids answering directly by mincing } \\
\text { words (Taira, 2008). } \\
\text { "Chyotto..." "Wakarimasennee..." } \\
\text { "I don't know." "I'm not sure..." }\end{array}$ \\
\hline Grounder & $\begin{array}{l}\text { The speaker gives reasons, explanations, or justifications for his/ } \\
\text { her inability to serve, which may either precede or follow it. } \\
\text { (Murakami modified; it originates from Blum-Kulka et al.1989) } \\
\text { "Uchi wa chiisai mise dakara...", } \\
\text { "Our store is such a small store..." }\end{array}$ \\
\hline Cajoler & $\begin{array}{l}\text { Conversationalized speech items whose semantic content is of } \\
\text { little transparent relevance to their discourse meaning. Cajolers } \\
\text { commonly do not enter into syntactic structures, but are } \\
\text { interspersed to increase, establish or restore harmony between the } \\
\text { interlocutors, which may be endangered through the request } \\
\text { (Blum-Kulka et al., 1989). } \\
\text { "Ano," "Hora," "Ne?" } \\
\text { "You know." }\end{array}$ \\
\hline Apology & $\begin{array}{l}\text { Apology used as opening or closing (Byon, 2004). } \\
\text { "Mooshiwake gozaimasen." "Sumimasen." } \\
\text { "I'm sorry, but..." }\end{array}$ \\
\hline $\begin{array}{l}\text { Intensifiers } \\
\text { (intensifying } \\
\text { adverbials) }\end{array}$ & $\begin{array}{l}\text { (Blum-Kulka et al., 1989) } \\
\text { "Hontooni," "Zitsuwa." } \\
\text { "very," "really," "actually." }\end{array}$ \\
\hline $\begin{array}{l}\text { Intensifiers } \\
\text { (emotional } \\
\text { expressions/ } \\
\text { exclamations) }\end{array}$ & $\begin{array}{l}\text { (Blum-Kulka et al., 1989) } \\
\text { "Aa," "Sooda!" } \\
\text { "Ah," "Oh.," }\end{array}$ \\
\hline $\begin{array}{l}\text { Factual } \\
\text { Information seeker }\end{array}$ & $\begin{array}{l}\text { In a situation, where the speaker does not know particular factual } \\
\text { information, the speaker seeks the information from the hearer } \\
\text { (Byon, 2004). } \\
\text { "-gozonzi desu ka?" } \\
\text { "Do you know-?" }\end{array}$ \\
\hline Suggestion & $\begin{array}{l}\text { The speaker suggests or provides the opinion directly, i.e. as a } \\
\text { locutionary act (Murakami added). } \\
\text { "Ookii omise ni ikanakucya ikemasen nee." "Ookii omise ni } \\
\text { ittara doodesuka?" } \\
\text { "You'll have to go to a bigger store." "Why don't you go to a }\end{array}$ \\
\hline
\end{tabular}




\begin{tabular}{|c|c|}
\hline & bigger store?" \\
\hline $\begin{array}{l}\text { Providing } \\
\text { information }\end{array}$ & $\begin{array}{l}\text { The speaker provides information to help achieving interlocutor's } \\
\text { need (Murakami added). } \\
\text { "Moosukosi sakini ooki suupaa ga arimasu yo." } \\
\text { "There is a big grocery store near here." }\end{array}$ \\
\hline $\begin{array}{l}\text { Downgrading } \\
\text { (Modal) }\end{array}$ & $\begin{array}{l}\text { Only optional subjunctive forms are coded as down graders; i.e., } \\
\text { indicatives have to be acceptable in the context (Blum-Kulka et } \\
\text { al., 1989). } \\
\text { "Suupaa ni wa arukamo siremasen." ("Suupaa ni ittara } \\
\text { doodesuka?") } \\
\text { "Might be better if you go to a supermarket." ("Be better if you } \\
\text { go to a supermarket.") }\end{array}$ \\
\hline $\begin{array}{l}\text { Downgrading } \\
\text { (Conditional) }\end{array}$ & $\begin{array}{l}\text { The conditional has to be optional to be coded as downgrading, } \\
\text { i.e. it has to be replaceable by an indicative form (Blum-Kulka et } \\
\text { al., 1989). } \\
\text { "Ookii mise ga iidesyoo nee." } \\
\text { "I would go to a bigger store." }\end{array}$ \\
\hline $\begin{array}{l}\text { Maintaining of the } \\
\text { relationship } \\
\text { positively }\end{array}$ & $\begin{array}{l}\text { The speaker mentions something that suggests maintaining the } \\
\text { relationship. } \\
\text { "Mata onegaisimasu." } \\
\text { "Please come again." }\end{array}$ \\
\hline $\begin{array}{l}\text { Encouragement/ } \\
\text { Sympathy/Caring, } \\
\text { Concern }\end{array}$ & $\begin{array}{l}\text { The speaker encourages or shows sympathy and concern (Taira, } \\
\text { 2008). } \\
\text { "Aru to iidesu ne." } \\
\text { "Good luck." }\end{array}$ \\
\hline Gratitude & $\begin{array}{l}\text { Appreciation used as closing } \\
\text { "Arigatoo gozaimasita." } \\
\text { "Thank you." "Thanks!" }\end{array}$ \\
\hline Response & $\begin{array}{l}\text { Simple response } \\
\text { "Hai" "Wakarimashita" } \\
\text { "OK." "Got it." }\end{array}$ \\
\hline
\end{tabular}

Based on the semantic formulas from the previous studies, possible scenarios and semantic formulas were established and used as a reference when the researcher recorded 
sales clerk's responses by hand after each data collection in the service encounter.

Possible scenarios and the coding manual are as follows:

\begin{tabular}{|c|c|c|}
\hline \multicolumn{3}{|c|}{ In the U.S. } \\
\hline \multicolumn{3}{|c|}{ C: Customer (Native English speaker), S: Sales clerk } \\
\hline 1 & C: Hi. & (Greeting) \\
\hline 2 & S: Hi. & (Greeting) \\
\hline 3 & C: Do you carry blue cheese here? & (Inquiry) \\
\hline 4 & S: No, we don't. & (Statement of Inability) \\
\hline 5 & $C:$ I really need some for my recipe tonight.. & (Insisting on the necessity) \\
\hline 6 & S: Um... & (Negative marker) \\
\hline 7 & C: Is there any grocery stores around here? & (Inquiry) \\
\hline 8 & S: Yeah, there is Safeway on this street. & (Providing information) \\
\hline 9 & C: Ok, thanks. & (Gratitude) \\
\hline
\end{tabular}

In Japan

$\mathrm{R}$ : Researcher (customer and Japanese native speaker)

S: Salesclerk

1 R: Sumimasen, buruu chiizu utte imasuka? (Inquiry)

2 S: Bruu chiizu desuka? Cyotto, uchini wa arimasen ga..

(Repetition of question + negative marker + Statement of inability)

3 R: Kyoo dooshitemo irun desukedo nee... (Insisting on the necessity) 

4 S: Mooshiwake arimasen, Uchi ni wa arimasen. (Apology + Statement of inability)
5 R: Soodesuka, Konohen ni uttesoona mise arimasuka. (Inquiry)
6 S: Ee, ookii misega chikaku ni arimasuyo. (Providing information)
7 R: Wakarimashita. Arigatoo gozaimasu. (Gratitude)
8 S: Arigatoogozaimasita. Mata onegai simasu.
(Gratitude +Maintaining of the relationship positively)

The actual coding started from line 4 after the customer's inquiry in the scenario because utterances 1 to 3 preceding the customer's inquiry are not significantly related to the purpose of this observation, that is, how people verbally compensate for the inability to meet the other's need.

\section{$\underline{\text { Data Analysis }}$}

- Natural speech sample from convenience stores

The natural speech samples obtained from convenience stores were documented by coding. The convention of coding follows the categorization of semantic formulas. The following examples demonstrate the process of the coding. Anticipated exchanges between a customer and a sales clerk are as follows:
C: Customer, S: Sales clerk
$1 \quad$ C: Do you have blue cheese?
2 S: No, we have other kinds though...
3 C: But I really need blue cheese for my recipe today. 


\begin{tabular}{|ll}
\hline 4 & S: There is a big grocery store over there. \\
5 & C: Thanks. I will check it out. \\
6 & S: Good luck.
\end{tabular}

If an exchange flowed as above, the sales clerk's utterances were coded as follows:

\begin{tabular}{|lll|}
\hline 1 & C: Do you have blue cheese? & (Customer Inquiry) \\
2 & S: No, we have other kinds though... & (Statement of inability) \\
3 & C: But I really need it today. & (Customer's insisting on the necessity of the item) \\
4 & S: There is a big grocery store over there. & (Providing information) \\
5 & C: Thanks. I will check it out. & (Greetings) \\
6 & S: Good luck. & (Encouragement)
\end{tabular}

Before proceeding with an analysis of natural speech samples, I examined the reliability of my coding. I asked a graduate student who is a native speaker of Japanese to code some speech samples from open-ended role-play by using semantic formulas to verify the reliability of my coding. I compared the sequence of my coding with the coding done by the graduate student, and also counted the number of matched semantic formulas within the Japanese and U.S. data. I provided the graduate student with two sound files of role-play from each country and the list of semantic formulas (Table 1) for coding. The graduate student coded only sales clerks' language behaviors as she listened to speech samples. The following is the data comparison between the researcher and the graduate student (second rater). 


\section{Table 2}

\section{Comparison of coding by semantic formulas between a graduate student and a researcher}

In Japan

Role-play sample 1

\begin{tabular}{|l|l|l|l|l|}
\hline Verbatim & \multicolumn{2}{|l|}{ Second Rater's coding } & \multicolumn{2}{l|}{ Researcher's coding } \\
\hline Sumimasen. & 1 & Apology & 1 & Apology \\
\hline Oite nai $\mathrm{n}$ desu & 2 & Statement of inability & 2 & Statement of inability \\
\hline Jitsuwa... & 3 & Intensifiers & 3 & Cajoler \\
\hline Suupaa ga arimasu yo. & 4 & Providing information & 4 & Providing information \\
\hline Arukamoshiremasen. & 5 & Modal & 5 & Modal \\
\hline $\begin{array}{l}\text { Suupaa ni ittemite } \\
\text { moraemasu ka. }\end{array}$ & 6 & Suggestion & 6 & Suggestion \\
\hline $\begin{array}{l}\text { Mooshiwake } \\
\text { gozaimasen. }\end{array}$ & 7 & Apology & 7 & Apology \\
\hline Ne? & 8 & Cajoler & & \\
\hline
\end{tabular}

Role-play sample 3

\begin{tabular}{|l|l|l|l|l|}
\hline Verbatim & \multicolumn{2}{|c|}{ Second Rater's coding } & \multicolumn{2}{l|}{ Researcher's coding } \\
\hline Buruu cheese desuka. & 1 & Repetition of question & 1 & Repetition of question \\
\hline Aa. & 2 & Negative marker & 2 & Negative marker \\
\hline Oite nai n desu. & 3 & Statement of inability & 3 & Statement of inability \\
\hline Mooshiwake arimasen. & 4 & Apology & 4 & Apology \\
\hline $\begin{array}{l}\text { (Providing info.) } \\
\text { Chikakuni suupaa ga } \\
\text { arimasu. } \\
\text { (Avoidance) } \\
\text { Wakarimasen. }\end{array}$ & 5 & Providing information & 5 & Avoidance \\
\hline $\begin{array}{l}\text { (Suggestion) } \\
\text { Ittemite morae } \\
\text { masuka. } \\
\text { (Providing info.) } \\
\text { Chikakuni suupaa ga } \\
\text { arimasu. }\end{array}$ & 6 & Suggestion & 6 & Providing information \\
\hline
\end{tabular}


In the U. S.

Role-play sample 1

\begin{tabular}{|c|c|c|c|c|}
\hline Verbatim & \multicolumn{2}{|r|}{ Second Rater's coding } & \multicolumn{2}{|r|}{ Researcher's coding } \\
\hline Hi. & 1 & Greeting & 1 & Greeting \\
\hline Blue cheese? & 2 & Repetition of question & 2 & Repetition of question \\
\hline Um. & 3 & Negative marker & 3 & Negative marker \\
\hline No, we don't. & 4 & Statement of inability & 4 & Statement of inability \\
\hline $\begin{array}{l}\text { (Apology) Sorry. } \\
\text { (Intensifier) Actually. }\end{array}$ & 5 & Apology & 5 & Intensifier \\
\hline $\begin{array}{l}\text { (Repetition) } \\
\text { Blue cheese. } \\
\text { (Apology) } \\
\text { Sorry. }\end{array}$ & 6 & Repetition & 6 & Apology \\
\hline $\begin{array}{l}\text { (Negative marker) } \\
\text { Well. } \\
\text { (Repetition of } \\
\text { question) } \\
\text { Blue cheese. }\end{array}$ & 7 & Negative marker & 7 & Repetition of question \\
\hline $\begin{array}{l}\text { (Cajoler) } \\
\text { You know. } \\
\text { (Negative marker) } \\
\text { Well. }\end{array}$ & 8 & Cajoler & 8 & Negative marker \\
\hline $\begin{array}{l}\text { (Suggestion) } \\
\text { A bigger store might } \\
\text { have. } \\
\text { (Negative marker) } \\
\text { Um. }\end{array}$ & 9 & Suggestion & 9 & Negative marker \\
\hline They might have. & 10 & Modal & 10 & Modal \\
\hline $\begin{array}{l}\text { (Cajoler) } \\
\text { You know. } \\
\text { (Suggestion) } \\
\text { A bigger store might } \\
\text { have. }\end{array}$ & 11 & Cajoler & 11 & Suggestion \\
\hline $\begin{array}{l}\text { (Avoidance) } \\
\text { I'm not sure. } \\
\text { (Negative marker) } \\
\text { Um. }\end{array}$ & 12 & Avoidance & 12 & Negative marker \\
\hline $\begin{array}{l}\text { (Providing info.) } \\
\text { There is a grocery } \\
\text { store that might have } \\
\text { blue cheese. } \\
\text { (Avoidance) }\end{array}$ & 13 & Providing information & 13 & Avoidance \\
\hline
\end{tabular}




\begin{tabular}{|c|c|c|c|c|}
\hline I'm not sure. & & & & \\
\hline $\begin{array}{l}\text { (Modal) } \\
\text { They might have. } \\
\text { (Providing info.) } \\
\text { There is a grocery } \\
\text { store that might have } \\
\text { blue cheese. }\end{array}$ & 14 & Modal & 14 & Providing information \\
\hline $\begin{array}{l}\text { (Providing info.) } \\
\text { There is a store around } \\
\text { here. } \\
\text { (Modal) } \\
\text { There might have. }\end{array}$ & 15 & Providing information & 15 & Modal \\
\hline $\begin{array}{l}\text { (Modal) } \\
\text { There might have. } \\
\text { (Providing info.) } \\
\text { There is a store around } \\
\text { here. }\end{array}$ & 16 & Modal & 16 & Providing information \\
\hline $\begin{array}{l}\text { (Avoidance) } \\
\text { I'm not sure. } \\
\text { (Intensifier) } \\
\text { I really don't know. }\end{array}$ & 17 & Avoidance & 17 & Intensifier \\
\hline $\begin{array}{l}\text { (Confirmation with } \\
\text { another co-worker) } \\
\text { Let me get someone to } \\
\text { ask. } \\
\text { (Negative marker) } \\
\text { Well. }\end{array}$ & 18 & $\begin{array}{l}\text { Confirmation with } \\
\text { another co-worker }\end{array}$ & 18 & Negative marker \\
\hline $\begin{array}{l}\text { (Negative marker) } \\
\text { Um. }\end{array}$ & & & 19 & Negative marker \\
\hline $\begin{array}{l}\text { (Avoidance) } \\
\text { I'm not sure. }\end{array}$ & & & 20 & Avoidance \\
\hline $\begin{array}{l}\text { (Intensifier) } \\
\text { Actually. }\end{array}$ & & & 21 & Intensifier \\
\hline $\begin{array}{l}\text { (Negative marker) } \\
\text { Um. }\end{array}$ & & & 22 & Negative marker \\
\hline $\begin{array}{l}\text { (Suggestion) } \\
\text { Why don't you go that } \\
\text { store. }\end{array}$ & & & 23 & Suggestion \\
\hline $\begin{array}{l}\text { (Intensifier) } \\
\text { I'm not sure. }\end{array}$ & & & 24 & Intensifier \\
\hline $\begin{array}{l}\text { Confirmation with } \\
\text { another co-worker) } \\
\text { Let me get someone to } \\
\text { ask. }\end{array}$ & & & 25 & $\begin{array}{l}\text { Confirmation with } \\
\text { another co-worker }\end{array}$ \\
\hline
\end{tabular}


Role-play sample 3

\begin{tabular}{|l|l|l|l|l|}
\hline \multicolumn{1}{|c|}{ Verbatim } & \multicolumn{2}{|c|}{ Second Rater's coding } & \multicolumn{2}{c|}{ Researcher's coding } \\
\hline I'm sorry.. & 1 & Apology & 1 & Apology \\
\hline No, we don't carry. & 2 & Statement of inability & 2 & Statement of inability \\
\hline Um. & 3 & Negative marker & 3 & Negative marker \\
\hline $\begin{array}{l}\text { No, we don't have } \\
\text { that. }\end{array}$ & 4 & Statement of inability & 4 & Statement of inability \\
\hline $\begin{array}{l}\text { There is a grocery } \\
\text { store that might have } \\
\text { it. }\end{array}$ & 5 & Providing information & 5 & Providing information \\
\hline It might have it. & 6 & Modal & & \\
\hline
\end{tabular}

The following demonstrates how I discarded some semantic formulas.

In Japan
Role-play 1
(Second Rater)
(Researcher)
1. Apology
1. Apology
2. Statement inability
2. Statement Inability
3. Intensifiers
3. Cajoler
4. Providing information
4. Providing information
5. Modal
5. Modal
6. Suggestion
6. Suggestion
7. Apology
7. Apology
8. Cajoler
Role-play 3
(Second Rater)
1. Repetition of question
2. Negative marker
3. Statement inability
4. Apology
5. Providing information
6. Suggestion
(Researcher)
1. Repetition of question
2. Negative marker
3. Statement of inability
4. Apology
5. Avoidance
6. Providing information 
In the U.S.

\begin{tabular}{|c|c|}
\hline \multicolumn{2}{|l|}{ Role-play 1} \\
\hline (Second rater) & (Researcher) \\
\hline 1. Greeting & 1. Greeting \\
\hline 2. Repetition of question & 2. Repetition of question \\
\hline 3. Negative marker & 3. Negative marker \\
\hline 4. Statement inability & 4. Statement of inability \\
\hline 5. Apology & 5. Intensifier \\
\hline 6. Repetition & 5. Apology \\
\hline 7. Negative marker & 6. Repetition of question \\
\hline 8. Cajoler & 7. Negative marker \\
\hline 9. Suggestion & 8. Negative marker \\
\hline 10. Modal & 9. Modal \\
\hline 11. Cajoler & 10. Suggestion \\
\hline 12. Avoidance & 11. Negative marker \\
\hline 13. Providing information & 12. Avoidance \\
\hline 14. Modal & 13. Providing information \\
\hline 15. Providing information & 14. Modal \\
\hline 16. Moda1- & 15. Providing information \\
\hline 16. Avoidance & 16. Intensifier \\
\hline 17. Confirmation with another co-worker & $\begin{array}{l}\text { 16. Negative marker } \\
\text { 19. Negative marker } \\
\text { 20. Avoidance } \\
\text { 21. Intensifier } \\
\text { 22. Negative marker } \\
\text { 23. Suggestion } \\
\text { 17. Intensifier } \\
\text { 18. Confirmation with another co-worker }\end{array}$ \\
\hline \multicolumn{2}{|l|}{ Role-play 3} \\
\hline (Second Rater) & (Researcher) \\
\hline 1. Apology & 1. Apology \\
\hline 2. Statement inability & 2. Statement of inability \\
\hline 3. Negative marker & 3. Negative marker \\
\hline 4. Statement inability & 4. Statement of inability \\
\hline $\begin{array}{l}\text { 5. Providing information } \\
6 . \text { Modat }\end{array}$ & 5. Providing information \\
\hline
\end{tabular}

As the comparison (Table 2) shows, although the majority of the coding matched on the semantic formulas such as apology, statement of inability, providing information, 
modal, and suggestion, there were gaps in the coding between the researcher and the second rater. In the Japanese samples, the researcher's coding was one line less than the second rater's, although the researcher's coding was longer than the second raters in the U.S. sample. For the Japanese samples, there were ten matches out of thirteen semantic formulas (this number came from the total number of the researcher's coding). As for the U.S. samples, ten matched semantic formulas out of twenty-nine semantic formulas. The gaps occurred because both raters were not consistent in including or excluding cajoler, intensifier, negative marker and avoidance. Therefore, after I looked at the discrepancies between the two raters' coding, I traced those semantic formulas that were not coded by both of them based on the transcript of role-play (Appendix C) and discarded them. I retained those negative markers and avoidance that were coded by both raters. That ultimately allowed me to obtain more accurate matching number and to establish consistency within my analysis.

Following the examination of the reliability of data coding, I analyzed natural speech samples quantitatively. After collecting data, I counted the frequency of each semantic formula and compared the frequencies and use of semantic formulas between Japan and the U.S. Afterwards, I focused on the order of semantic formulas, specifically how the conversation developed after the inquiry about blue cheese from the customer. In order to examine the order of semantic formulas, I qualitatively analyzed data by applying the concept of adjacency pair proposed by Sacks and Schegloff and Jefferson (1973). According to them, there are some qualifications to be considered as an adjacency pair, that is, two utterances length, different person utters each sentence and 
the unit can be isolated in the whole discourse (1973, p. 295-296). Examples of an adjacency pair are "question and answer" and "offer and acceptance or rejection." Since I hypothesized that sales clerks would provide information to the customer to achieve their need by proxy, I assumed that the sequence of exchange between a sales clerk and a customer sometimes would not be linguistically coherent at the surface level. I focused on what kind of adjacency pairs are embedded in a discourse, and the order of its appearance. The following examples illustrate the process of identifying an adjacency pair in this study.

Example A:
C: Customer, S: Salesclerk
1 C: Do you have blue cheese?
2 S: No, we don't.

In Example A, line 1 and line 2 are considered to be a normal adjacency pair because line 1 "Do you have blue cheese?" is a yes-no question, and the following utterance by the sales clerk "No" in line 2 is the answer, which comprises a question-answer pair.

However consider Example B.

Example B:
C: Customer, S: Salesclerk
$1 \quad$ C: Do you have blue cheese?
2 S: Um, we have cheddar... 
In Example B, line 1 and 2 are also categorized as an adjacency pair of question-answer. In order to produce a grammatical response to the question of line 1, a sales clerk should respond to a customer with yes, or no. However, the sales clerk's utterance line 2 "Um, we have cheddar..." is interpreted by a customer as the response to the question, namely "no," because if the store does not carry blue cheese, the sales clerk does not have to provide the alternative item to blue cheese. Thus, the pair consisting of " Do you have blue cheese?" and "Um, we have cheddar" is a question-answer relationship, namely, an adjacency pair. According to Merritt (1976), this kind of interpretation occurs due to a customer's pragmatic interpretation. The customer considers that the response "Um, we have cheddar" is pragmatically relevant to the customer's knowledge of service encounter, and the context in which the customer is engaged. The following is another example of finding an adjacency pair in possible exchanges in this study.

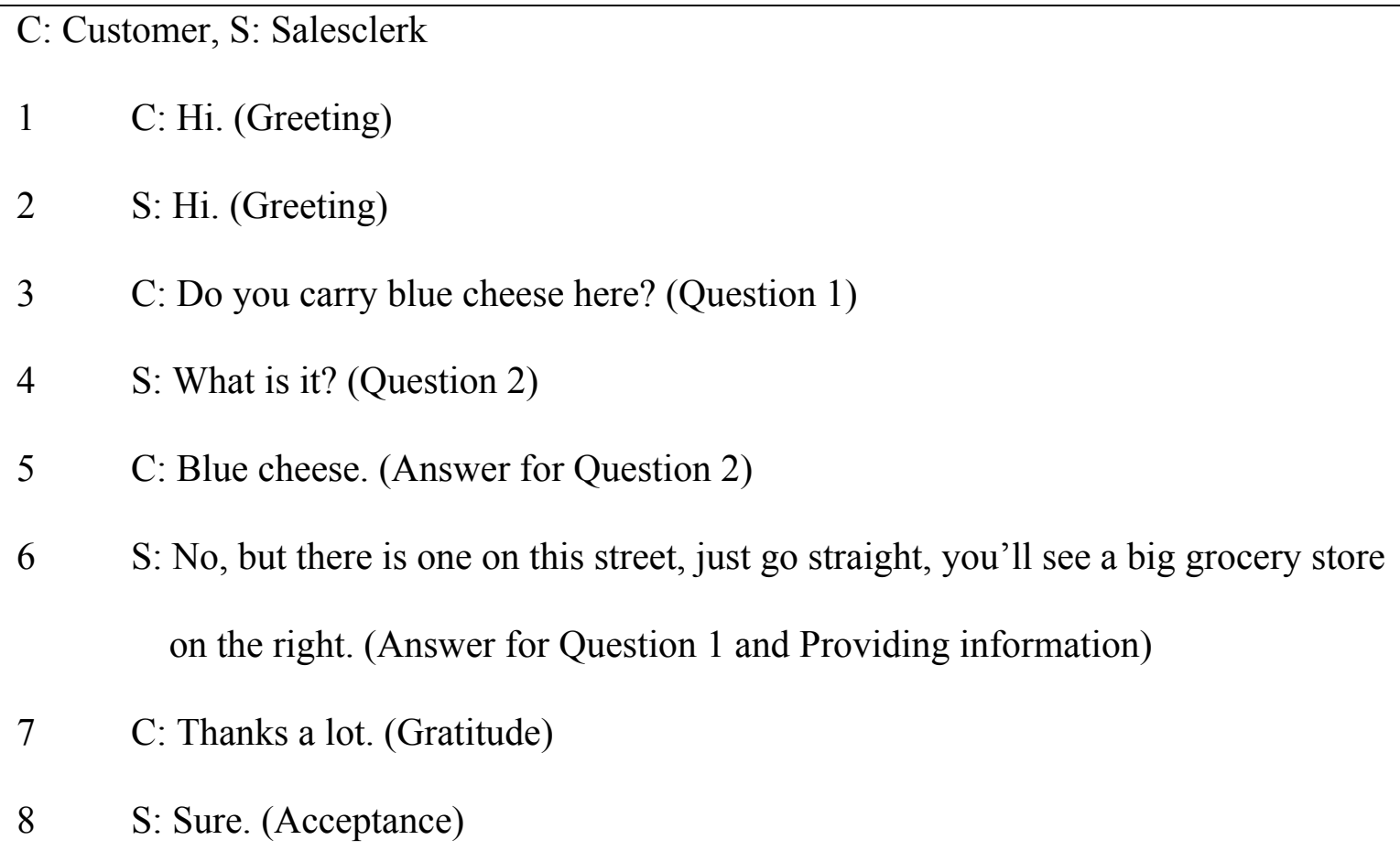
on the right. (Answer for Question 1 and Providing information)

7 C: Thanks a lot. (Gratitude)

8 S: Sure. (Acceptance) 
In this exchange, there are four adjacency pairs: Line 1-2, Greeting-Greeting, Line3-6, Question Answer, Line 4-5, inserted Question-Answer and line 7-8, Gratitude-

\section{Acceptance}

I identified adjacency pairs in a natural oral sample as the examples above show, and examine the relationship of each utterance in a pair.

Furthermore, as mentioned in the previous chapter, the discourse generated in service encounters is institutional talk similar to the interaction in courthouses, hospitals, schools, and so forth. In the institutional setting, the utterances of participants are constrained by the setting in which they are involved, and also, their institutional or professional identities pertinent to their work activities. In the analysis, I referred to Grice's cooperative principles, which consist of four categorizations: quantity, quality, relation, and manner (1975, p. 45). These categorizations are used to discover reasons for the generation of utterances at each point and whether the utterances are constrained by the service encounter setting. That ultimately allowed me to examine how the utterances function as a count of an adjacency pair, and simultaneously the mechanism of compensation for a face-threatening act (FTA) in different cultures.

Furthermore, in order to examine the characteristics of an FTA, I first identified the semantic formulas which are classified as a demonstration of politeness by Brown and Levinson (1987) and also exist in Japanese and English, such as a modal or silence. I counted the frequency of such semantic formulas and compare the politeness in service encounters in Japan and the U.S. Second, I explored whose and which faces were violated in each utterance. The following is an example of how I identify an FTA. 


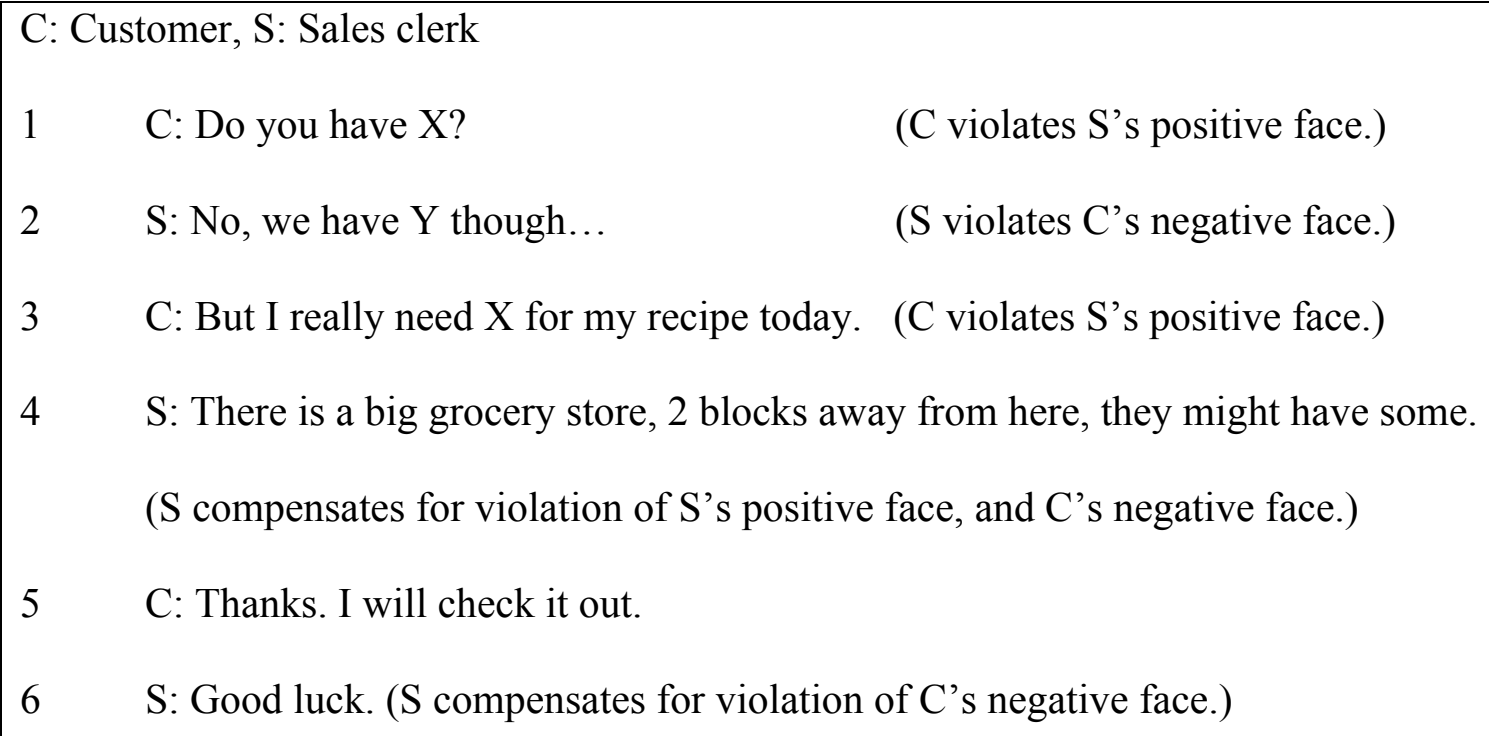

- Open-ended oral role-play

First, the recorded speech in role-playing was transcribed. After transcribing, I coded by semantic formulas and analyze politeness features used in the natural oral sample as well. I compared the length of the sequence of semantic formulas between open-ended oral role-play and natural speech sample. The following is the constructed examples.
C: Customer (Researcher), S: Sales clerk (Participant)
1 C: Hi.
2 S: Hi.
3 C: Do you have blue cheese here?
$4 \quad$ S: What is it?
5 C: Blue cheese.
6 S: No, but there is a store on this street, just go straight, 


\begin{tabular}{|l} 
you'll see a big grocery store on the right. \\
$7 \quad$ C: Thanks a lot. \\
$8 \quad$ S: Sure.
\end{tabular}

If an exchange in a role-play flows like this, it will be coded as follows:

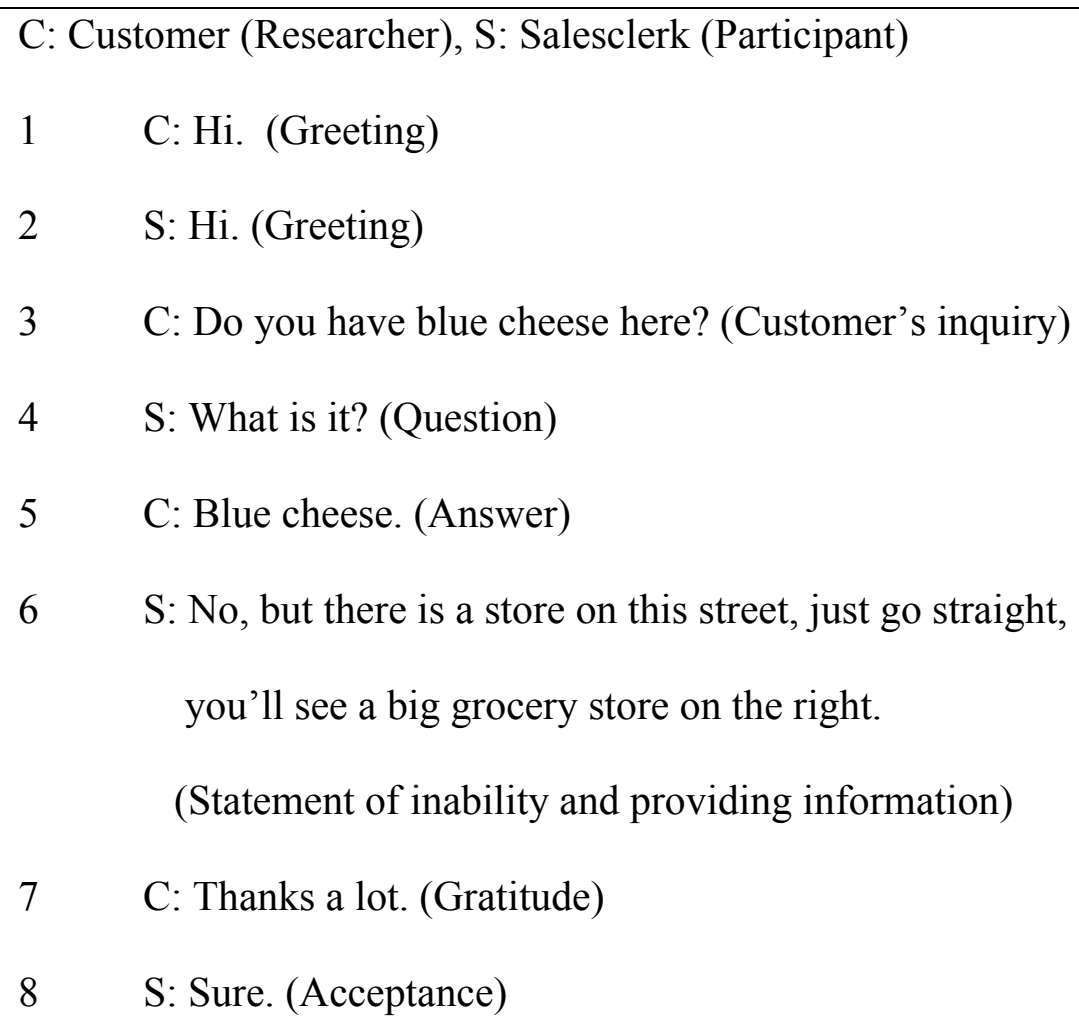

After coding, I compared the data of a natural speech sample and role-playing to find out if there were any differences between the two data sets. The data from role-play allowed me to analyze details of the utterance, whereas natural data does not contain such detailed verbatim because it was documented by coding only. If the order of semantic formulas 
from role-playing resembles the one from natural data, it would allow us to assume the detail collected from role-playing could have occurred in natural data. 


\section{CHAPTER 4}

\section{Results}

This chapter presents results from the data collection of the natural speech sample and the open-ended role-play situations in four sections. In the first section, I present the frequencies of semantic formulas and primary differences between Japan and the U.S. In the second section, I present what kind of adjacency pairs are embedded in the sequences of exchanges between a customer and sales clerks. In the third section, I demonstrate the sequence of face-threatening acts and how it is related to sales clerks' compensation for their inability. In the last section, I compare the sequence of semantic formulas between natural speech samples and open-ended role-play.

Frequency of Semantic formulas

After collecting each speech sample, I counted the appearance of semantic formulas. That data demonstrated that Japanese sales clerks used more varieties of semantic formulas than American sales clerks. Some semantic formulas were only used in Japan. Simultaneously, there were some semantic formulas that did not entirely appear in the discourse both in Japan and the U.S. Table 3 and Figure 1 demonstrate the distributions of semantic formulas. The percentage represents the rate of each semantic formula in each country.

\section{Table 3}

\section{The frequency of semantic formulas}

\begin{tabular}{|l|c|r|}
\hline & Japan & The U.S. \\
\hline Repetition of Question & $8(14.0 \%)$ & $2(5.7 \%)$ \\
\hline Statement of Inability & $5(8.8 \%)$ & $18(51.4 \%)$ \\
\hline Providing Alternative items & $4(7.0 \%)$ & $0(0.0 \%)$ \\
\hline Negative Marker & $5(8.8 \%)$ & $0(0.0 \%)$ \\
\hline Avoidance & $5(8.8 \%)$ & $0(0.0 \%)$ \\
\hline
\end{tabular}




\begin{tabular}{|l|r|r|}
\hline Apology & $2(3.5 \%)$ & $1(2.9 \%)$ \\
\hline Confirmation with another co-worker & $3(5.3 \%)$ & $1(2.9 \%)$ \\
\hline Providing Information & $6(10.5 \%)$ & $7(20.0 \%)$ \\
\hline Downgrading (Modal) & $7(12.3 \%)$ & $1(2.9 \%)$ \\
\hline Silence & $4(7.0 \%)$ & $2(5.7 \%)$ \\
\hline Suggestion & $1(1.8 \%)$ & $0(0.0 \%)$ \\
\hline Encouragement & $1(1.8 \%)$ & $0(0.0 \%)$ \\
\hline Gratitude & $6(10.5 \%)$ & $0(0.0 \%)$ \\
\hline Greeting & $0(0.0 \%)$ & $3(8.6 \%)$ \\
\hline & & \\
\hline Total & $57(100 \%)$ & $35(100 \%)$ \\
\hline
\end{tabular}

\section{Figure 1}

\section{The frequency of semantic formulas}

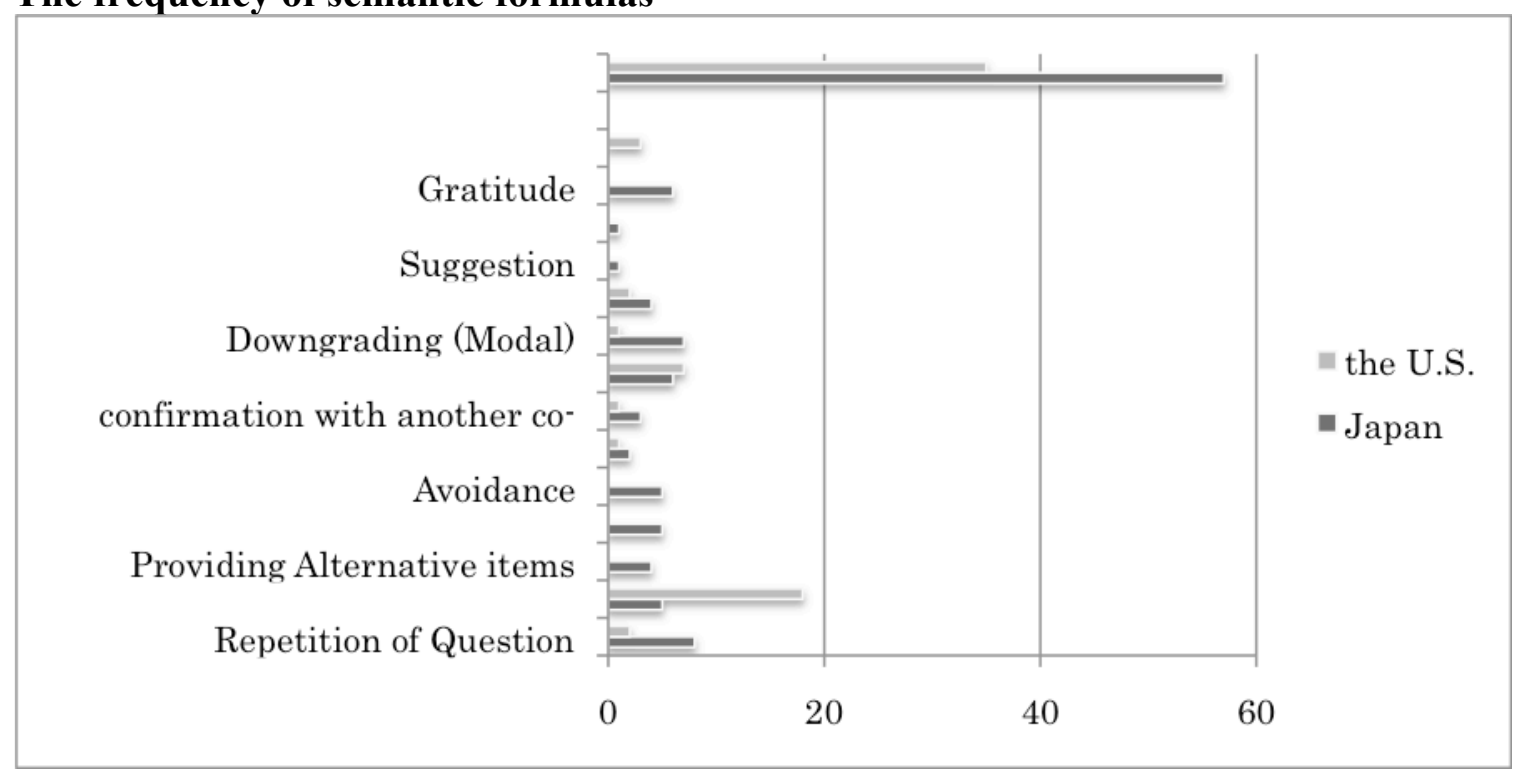

Table 3 and Figure 1 above exhibit the frequencies of different semantic formulas.

Some semantic formulas appeared in both Japan and the U.S. However, there were semantic formulas that were only used in Japan: providing alternative items, a negative marker, avoidance, suggestion, encouragement, and gratitude. On the other hand, greeting appeared toward the end only in the U.S such as, "Have a good one." The frequency of each semantic formula illustrates the mechanism of compensation for the sales clerk's 
inability to meet customer's need. Although there are differences in the frequency of semantic formulas between Japan and the U.S., the salient difference was the frequency of a statement of inability.

In the U.S., a statement of inability was represented by almost fifty percent of the total use of semantic formulas, while it was eight percent of the total use of semantic formulas in Japan. This is a common example in Japan and the U.S.

In the U.S.
Speech sample 9
1 C: Customer's inquiry
2 S: Statement of inability
3 C: Customer's insisting on the necessity of the item
4 S: Statement of inability
5 C: Customer's inquiry about other stores
$6 \quad$ S: Statement of inability

The exchanges such as speech sample 9 were frequently observed in the U.S. The italic sentences are customer's utterances. The sales clerk continued to demonstrate a "statement of inability" after each of the customer's utterances. As opposed to the sequence of semantic formulas in the U.S., Japanese sales clerks demonstrated different language behaviors. Here is one of the examples that was typical of the observations in Japan. 
In Japan

\begin{tabular}{|ll}
\hline $\begin{array}{l}\text { Speech sample } 3 \\
1\end{array}$ & C: Customer's inquiry \\
2 & S: Repetition of question \\
3 & Negative marker \\
4 & Avoidance \\
5 & Providing alternative item \\
6 & C: Customer's insisting on the necessity of the item \\
7 & S: Silence \\
8 & C: Customer's inquiry about other stores \\
9 & S: Suggestion \\
10 & Gratitude
\end{tabular}

Compared to the previous U.S. speech sample 9, four different semantic formulas appeared between customer's first utterance and the second utterance. Moreover, in speech sample 3, there was no "statement of inability." Instead, the sales clerks demonstrated different utterances such as "negative marker" and "avoidance." Those were one of the examples from natural speech samples; therefore, there were different types of the sequences of semantic formulas demonstrated by other sales clerks; yet, the "statement of inability" was more frequently used in the U.S. than Japan overall. 
As for the frequencies of semantic formulas, I counted how many sales clerks spontaneously provided alternative items to blue cheese and information that helps the customer to obtain the product.

\section{Table 4}

The frequency of spontaneously providing alternative items in Japan and the U.S.

\begin{tabular}{|c|c|}
\hline Japan & The U.S. \\
\hline $5 / 11$ & $0 / 10$ \\
\hline
\end{tabular}

Almost half of the sales clerks in Japan spontaneously provided alternative items to blue cheese, whereas none of the sales clerks provided alternative items in the U.S. In Japan, sales clerks tended to provide alternative items as a response to customer's first inquiry "Do you carry blue cheese?" Here are the examples as follows:

In Japan
Speech sample 3
1 C: Customer's inquiry
2 S: Repetition of question
$3 \quad$ Negative marker
$4 \quad$ Avoidance
5 Providing alternative item
6 C: Customer's insisting on the necessity of the item
$7 \quad$ S: Silence
8 C: Customer's inquiry about other stores
$9 \quad$ S: Suggestion 
$10 \quad$ Gratitude

\begin{tabular}{|c|c|}
\hline \multicolumn{2}{|c|}{ Speech sample 5} \\
\hline 1 & C: Customer's inquiry \\
\hline 2 & S: Providing alternative items (check out the shelf) \\
\hline 3 & C: Customer's insisting on the necessity of the item \\
\hline 4 & S: Repetition of question \\
\hline 5 & Providing information + Modal \\
\hline 6 & Apology \\
\hline 7 & Gratitude \\
\hline
\end{tabular}

In speech sample 3, "providing alternative items" appears as the fourth utterance from customer's first utterance. Since there was no customer's utterance that directly asks about alternative items between him/her, it is relevant that "providing information" occurred spontaneously. In example 5, "providing information” appears right after “customer's inquiry;" therefore, this also occurred spontaneously.

Moreover, in this study, besides “customer's inquiry," a customer uttered two different phrases contingent upon the sales clerk's responses. Table 5 presents what semantic formulas followed the customer's insisting on the need for the blue cheese in Japan and the U.S.: 
Table 5

Semantic formulas following the "customer's insisting on the necessity of the item"

\begin{tabular}{|l|r|r|}
\hline & Japan (11) & U.S. (10) \\
\hline Providing information & 4 & 2 \\
\hline $\begin{array}{l}\text { Confirm with another } \\
\text { co-worker }\end{array}$ & 1 & 1 \\
\hline Statement of inability & 1 & 5 \\
\hline Silence & 4 & 2 \\
\hline Encouragement & 1 & 0 \\
\hline Modal & 2 & 0 \\
\hline Avoidance & 2 & 0 \\
\hline Negative marker & 10 & 0 \\
\hline & & \\
\hline Total & 25 & 10 \\
\hline
\end{tabular}

As Table 5 indicates, "providing information" spontaneously appeared in both Japan and the U.S. This appeared four times in Japan, while it occurred two times in the U.S. Those sales clerks provided the information without being explicitly asked. The following examples demonstrate how the exchanges between a customer and a sales clerk developed after the second utterance of customer, i.e., "customer's insisting on the necessity of the item."

In Japan
Speech sample 1
1 C: Customer's inquiry
2 S: Negative marker + Providing alternative items
3 C: Customer's insisting on the necessity of the item
4 S: Providing information
$5 \quad$ Gratitude

In the U.S. 
Furthermore, Japanese sales clerks used more semantic formulas than U.S. sales clerks. Salient differences between Japan and the U.S. were observed in the use of the "statement of inability" and "silence." U.S. sales clerks demonstrated a "statement of inability" more than Japanese sales clerks, and Japanese sales clerks used "silence" more frequently. The following are the examples from Japan and the U.S.:

In Japan
Speech sample 2
1 C: Customer's inquiry
2 S: Repetition of question
$3 \quad$ Negative marker
4 C: Customer's insisting on the necessity of the item
5 S: Silence
6 C: Customer's inquiry about other stores
7 S: Providing information + Modal + Modal + Modal 
In the U.S.
Speech sample 5
1 C: Customer's inquiry
2 S: Statement of inability
3 Apology
$4 \quad \mathrm{C}$ : Customer's insisting on the necessity of the item
$5 \quad$ S: Statement of inability
6 C: Customer's inquiry about other stores
$7 \quad$ Providing information + Modal

The third customer utterance is the explicit inquiry about other stores that might carry blue cheese. Table 6 shows that the semantic formulas appeared after the "customer's inquiry about other stores."

Table 6

Semantic formulas following after the "customer's inquiry about other stores"

\begin{tabular}{|l|r|r|}
\hline & Japan (11) & U.S. (10) \\
\hline Providing Information & 4 & 4 \\
\hline Modal & 4 & 1 \\
\hline Suggestion & 1 & 0 \\
\hline Statement of inability & 1 & 3 \\
\hline & & \\
\hline Total & 10 & 8 \\
\hline
\end{tabular}

The Table 6 shows the token of the occurrence of semantic formulas after the "customer's inquiry about other stores." This inquiry did not necessary occur in each exchanges because some sales clerks already provided information when a customer insisted on the necessity of an item. In fact, " inquiry about other stores" occurred six 
times in Japan, and seven times in the U.S.; therefore, the total number of semantic formulas does not correspond to the number of sales clerks. Since the customer's utterance clearly asked for the information, "providing information" appears in Japan and the U.S. Moreover, Japanese sales clerks demonstrated more use of a modal such as “...kamo shiremasen," translated "It might be..." than U.S. sales clerks.

\section{$\underline{\text { Adjacency Pairs }}$}

According to Sacks and Schegloff (2006), discourses need to satisfy following conditions to be considered as an adjacency pair sequence (p. 265):

(1) Two utterance length

(2) Adjacent positioning of component utterances

(3) Different speakers producing each utterance

(4) Relative ordering of parts (i.e. first pair parts precede second pair parts)

(5) Discriminative relations (i.e. the pair type of which a first pair parts is a member is relevant to the selection among second pair parts)

I examined what kind of adjacency pairs were embedded in the discourse between a customer and sales clerk. Since the customer's first and the third utterances were questions, explicit answers followed the questions by sales clerks — an adjacency pair of question and answer was observed.

In Japan
Speech sample 3
$1 \quad$ Q1 C: Customer's inquiry
2 A1 S: Repetition of question
3 A1 Negative marker
$4 \quad$ A1 Avoidance 


\begin{tabular}{|lcc}
5 & A1 & Providing alternative item \\
6 & C: Customer's insisting on the necessity of the item \\
7 & S: Silence \\
8 & Q2 C: Customer's inquiry about other stores \\
9 & A2 S: Suggestion \\
10 & Gratitude
\end{tabular}

In the U.S.
Speech sample 4
1 Q1 C: Customer's inquiry
2 A1 S: Statement of inability
3 C: Customer's insisting on the necessity of the item
$4 \quad$ S: Silence
5 Q2 C: Customer's inquiry about other stores
6 A2 S: Providing information
$7 \quad$ C: Greeting

However, in Japan, there were cases where no explicit answer followed the first question in Japan. After customer's question 1 occurred, there was no explicit answer to question 1 until the second utterance of a customer. Rather, the sales clerk demonstrated a different language behavior as a replacement for the statement of inability, such as negative 
marker, avoidance, or providing an alternative item. Namely, there was no or little coherence at the surface level in terms of a pair of questions and answers.

The natural speech sample indicated that there was an adjacency pair of questions and answers, such as “customer's inquiry-providing alternative items," in Japan and the U.S. However, sales clerk's answers were different in Japan and the U.S. In the first adjacency pair in Japanese speech sample 3, there was no "statement of inability" and sales clerks used several semantic formulas as an answer. This explains that the sales clerk avoided causing a direct face-threatening act, and implied his/her inability to service the customer by his/her long discourse. In the U.S. speech sample 4, the first adjacency pair was a total of two utterances, which demonstrated that the sales clerk did not hesitate to cause a face-threatening act.

In terms of the relationship between the second utterance of a customer, "customer's insisting on the necessity of the item" and the response by sales clerks, these utterances were not identified as an adjacency pair because "customer's insisting on the necessity of the item" is not a question, it is a statement.

In Japan
Speech sample 6
$1 \quad \mathrm{C}:$ Customer's inquiry
2 S: Repetition of question
(Checking out shelf)
3 Providing alternative items
$4 \quad$ Statement of inability 
5 C: Customer's insisting on the necessity of the item

$6 \quad$ S: Providing information + Modal

In the U.S.

$\begin{array}{ll}\text { Speech sample 2 } \\ 1 & \text { C: Customer's inquiry } \\ 2 & \text { S: Statement of inability } \\ 3 & \text { C: } \text { Customer's insisting on the necessity of the item } \\ 4 & \text { S: Providing information } \\ 5 & \text { Greeting }\end{array}$

Speech sample 4

1 C: Customer's inquiry 


\begin{tabular}{|ll}
2 & S: Statement of inability \\
3 & C: Customer's insisting on the necessity of the item \\
4 & S: Silence \\
5 & C: Customer's inquiry about other stores \\
6 & S: Providing information \\
7 & Greeting
\end{tabular}

These examples exhibit that "providing information" and "silence" appeared after the “customer's insisting on the necessity of the item." Even though different speakers spoke these utterances and they appeared adjacently, the two utterances should not be considered an adjacency pair because "customer's insisting on the necessity of the item" is a statement, not a question.

\section{Compensation Efforts}

Each customer's utterance was designed to elicit the sales clerk's utterance. The intention of the first utterance especially, asking for blue cheese, was used to create the situation that a sales clerk has to cause a face-threatening act. Since he/she does not carry blue cheese, he/she had to somehow inform the customer. Being unable to accommodate customer's need violates customer's negative face. The customer wishes to fulfill his/her want for a product to be unimpeded, which simultaneously violates sales clerk's positive face, his want to be desirable. This forces the sales clerk to inform the customer of his/her inability to service the customer. In analyzing these face-threatening acts, I focused on the frequency of a modal and silence because it represents the politeness of the speaker 
explained by Brown and Levinson (1987, p.191, 275, 295). Moreover, both Japanese and English possess modal expressions such as "...kamo shiremasen" in Japanese and "it might, it could..." in English. The Table 7 shows the number of sales clerks who used modal expression in Japan and the U.S.

- The frequencies of a "modal"

Table 7

The number of sales clerks who used a modal expression in Japan and the U.S.

\begin{tabular}{|c|c|c|}
\hline & Japan & The U.S. \\
\hline Modal & $6 / 11$ & $1 / 10$ \\
\hline
\end{tabular}

Modal expressions in Japanese such as kamoshiremasen (meaning roughly could or might) tended to appear with sales clerks' providing information of other stores in both Japan and the U.S. Since the majority of sales clerks in Japan used a modal expression, whereas only one sales clerk used modal in the U.S. Therefore, it is relevant to assume that Japanese sales clerks were more conscious about the politeness than U.S. sales clerks.

- The frequencies of 'silence'

\section{Table 8}

The number of sales clerks who used silence in Japan and the U.S.

\begin{tabular}{|c|c|c|}
\hline & Japan & The U.S. \\
\hline Silence & $4 / 11$ & $2 / 10$ \\
\hline
\end{tabular}

Silence always occurred after a customer insisted on his/her necessity of blue cheese. Table 8 shows the number of sales clerks who used silence in Japan and the U.S. Instead of saying something to a customer, sales clerks did not utter anything at all. Since saying something can violate a customer's or sales clerk's own face, it is possible to 
assume that "silence" is also the expression of the speaker's politeness. Japanese sales clerks demonstrated "silence" more frequently than the U.S. sales clerks.

- The length of one response

The length of sales clerks' responses to "customer's insisting on the necessity of the item" and the "customer's inquiry about other stores" varied in Japan and the U.S. The data shows a tendency of Japanese sales clerks to use longer responses than their U.S. counterparts. Japanese sales clerks tended to demonstrate two phrase utterances as one response, while U.S. sales clerks uttered one phrase for a response. In the U.S., the combination of providing information and a modal expression appeared only once. However, Japanese sales clerks use more combinations as follows: In Japan

Speech sample 2, C: Providing information + Modal Speech sample 4, C: Providing information + encouragement Speech sample 7, C: Silence + Avoidance Speech sample 8, C: Providing information + Modal + Modal + Modal

The modal expressions in the speech samples above were always "Soko wa arukamoshiremasen (That place might have it.)." By means of using a modal expression as a combination of providing information, sales clerks could lessen their certainty, and could mitigate a potential face-threatening act. If the store that a sales clerk suggests to the customer might have blue cheese does not carry blue cheese, that violates both the customer's negative face and the sales clerk's positive face simultaneously. 
- The length of entire exchanges in one encounter

Not only the length of each response, but also the length of whole exchanges between a customer and sales clerks varied (see Appendix A). The following examples show the basic length of exchanges that the majority of sales clerks exhibited in Japan and the U.S. respectively. In Japan
Speech sample 1
$1 \quad \mathrm{C}:$ Customer's inquiry
2 S: Negative marker + Providing alternative items
3 C: Customer's insisting on the necessity of the item
4 S: Providing Information
Gratitude

In the U.S.
Speech sample 9
1 C: Customer's inquiry
2 S: Statement of inability
3 C: Customer's insisting on the necessity of the item
4 S: Statement of inability
5 C: Customer's inquiry about other stores
6 S: Statement of inability 
The following examples are longer encounters than the previous examples.

In Japan

\begin{tabular}{|cc}
\hline Speech sample 3 \\
1 & C: Customer's inquiry \\
2 & S: Repetition of question \\
3 & Negative marker \\
4 & Avoidance \\
5 & Providing alternative item \\
6 & C: Customer's insisting on the necessity of the item \\
7 & S: Silence \\
8 & C: Customer's inquiry about other stores \\
9 & S: Suggestion \\
10 & Gratitude
\end{tabular}

Speech sample 6

$1 \quad \mathrm{C}:$ Customer's inquiry

2 S: Repetition of question (Checking out shelf)

3 Providing alternative item

$4 \quad$ Statement of inability

5 C: Customer's insisting on the necessity of the item

6 S: Providing information + Modal 
In the U.S.
Speech sample 1
1 S: Alerter (attention-getter)+ Alerter (Title)
2 C: Customer's inquiry
3 S: Statement of inability
4 C: Customer's insisting on the necessity of the item
5 S: Confirm with another co-worker
$6 \quad$ Silence
$7 \quad$ C: Customer's inquiry about other stores
8 S: Providing information
$9 \quad$ Greeting

\author{
Speech sample 4 \\ 1 C: Customer's inquiry \\ 2 S: Statement of inability \\ 3 C: Customer's insisting on the necessity of the item \\ 4 S: Silence \\ 5 C: Customer's inquiry about other stores \\ 6 S: Providing information \\ $7 \quad$ Greeting
}


The examples demonstrate how Japanese sales clerks uttered more than U.S. sales clerks especially after the inquiry for blue cheese. Figure 2 and 3 indicate the length of exchanges in Japan and the U.S.

\section{Figure 2}

The length of exchanges in Japan

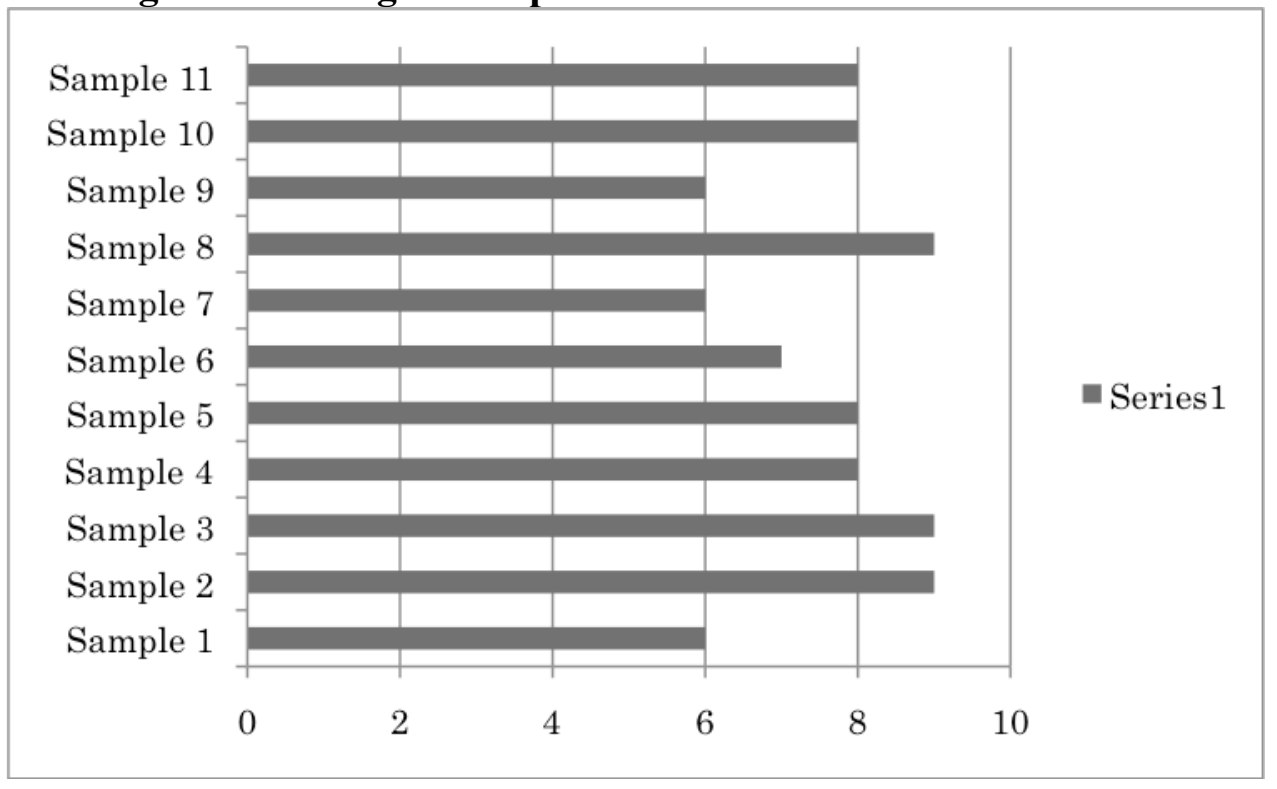

\section{Figure 3}

\section{The length of exchanges in the U.S.}

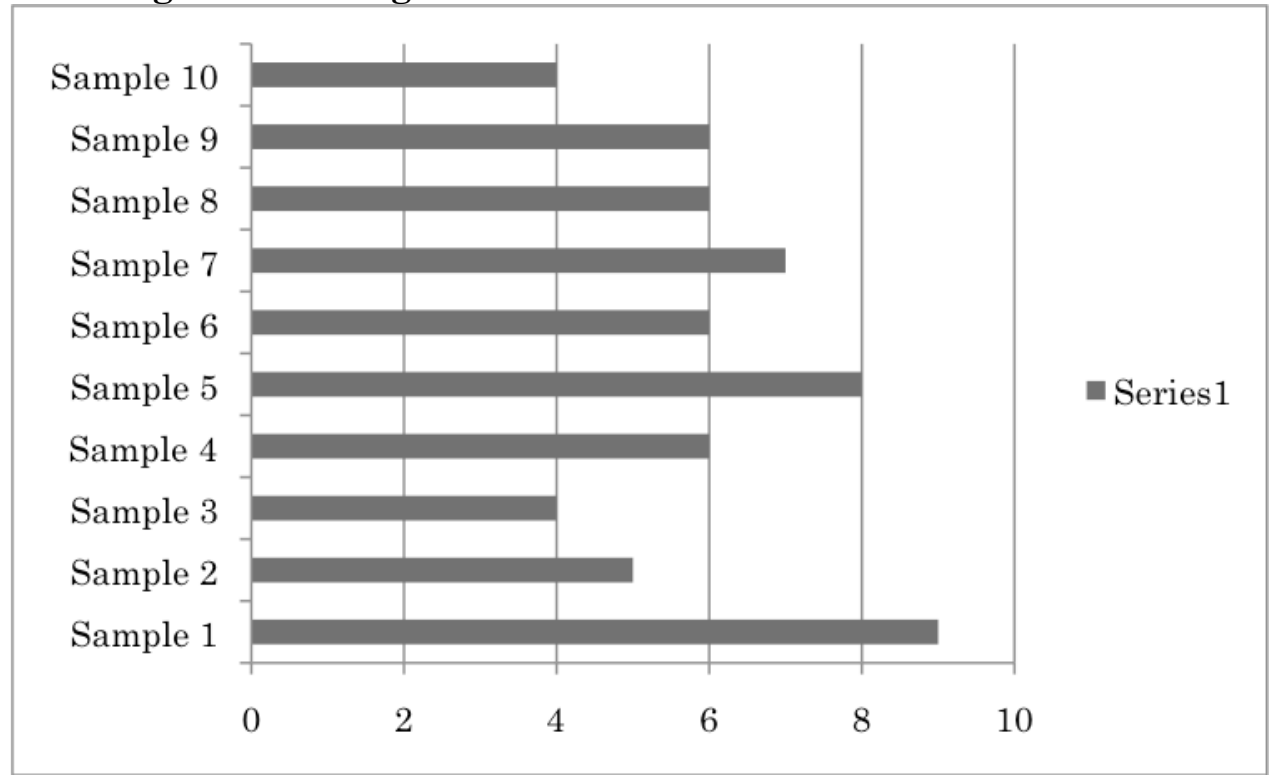


The average total length of exchanges was seven turns in Japan and six in the U.S. "Silence" was not excluded. The shortest length of the total exchanges in Japan was six turns, and it was four turns in the U.S. The longest exchange in Japan and the U.S. was nine turns. The length of exchanges varied depending on how sales clerks avoid a facethreatening act. Some sales clerks delayed the statement of inability or did not state their inability by inserting several semantic formulas until a customer's second utterance.

- The occurrence of "providing information"

"Providing information" appeared both before and after the second utterance of a customer, "customer's insisting on the necessity of the item"-_I really need some for my recipe," and the third utterance, "customer's inquiry about other stores"- "Do you know any other grocery stores around here?" both in Japan and the U.S. The Table 9 demonstrates the occurrence of providing information following a “customer's insisting on the necessity of the item," or "customer's inquiry about other stores."

\section{Table 9}

The occurrence of "providing information" following "customer's insisting on the necessity of the item," or "customer's inquiry about other stores"

\begin{tabular}{|l|c|c|}
\hline & Japan (11) & The U.S. (10) \\
\hline $\begin{array}{l}\text { Following the "customer's } \\
\text { insisting on the necessity of } \\
\text { the item" }\end{array}$ & 4 & 2 \\
\hline $\begin{array}{l}\text { Following the "customer's } \\
\text { inquiry about other stores" }\end{array}$ & 4 & 4 \\
\hline
\end{tabular}

"Providing information" was used more frequently in Japan than the U.S after a customer's insistence on the item. However, in terms of the timing of the occurrence, providing information occurred four times in both Japan and the U.S. following 
“customer's inquiry about other stores.” Regarding the spontaneity of providing information, the appearance after a "customer's inquiries about other stores" needs to be excluded because this inquiry directly asks for the information. Thus, "providing information" spontaneously occurred four times in Japan, and two times in the U.S. Comparison of natural speech sample and open-ended role-play

- The differences between natural speech samples and open-ended role-play

In this study, the researcher collected two different types of data: a natural speech sample and an open-ended role-play. Data represented prominent differences between the natural speech sample and the open-ended role-play, and its characteristics were also different in Japan and the U.S (see Appendix A and B). The data of both Japan and the U.S. showed that sequences of semantic formulas of the natural speech sample were much shorter than open-ended role-plays. This explains that the participants of roleplaying generated more utterance than actual sales clerks in convenience stores. Moreover, role-playing data represented the frequent use of an "intensifier," "modal," "negative marker," "avoidance," and "apology;" moreover, some of semantic formulas rarely appeared in natural speech samples. Here is the example as follows: In Japan

\begin{tabular}{|c|c|}
\hline Role-play 1 & Natural speech sample 1 \\
\hline $1 \mathrm{C}:$ Alerter & $1 \mathrm{C}$ : Customer' $\mathrm{s}$ inquiry \\
\hline Customer' s inquiry & $2 \mathrm{~S}:$ Negative marker \\
\hline 3 S: Apology & 3 Providing alternative items \\
\hline Statement of inability & $4 \mathrm{C}$ : Customer's insisting on the necessity of the item \\
\hline
\end{tabular}


5 C: Customer's insisting on the necessity of the item 5 S: Providing information

6 S: Cajoler

6 C: Gratitude

7 Providing information

8 Modal

9 Suggestion

10 C: Response

11 S: Apology

12 C: Gratitude

In the U.S.

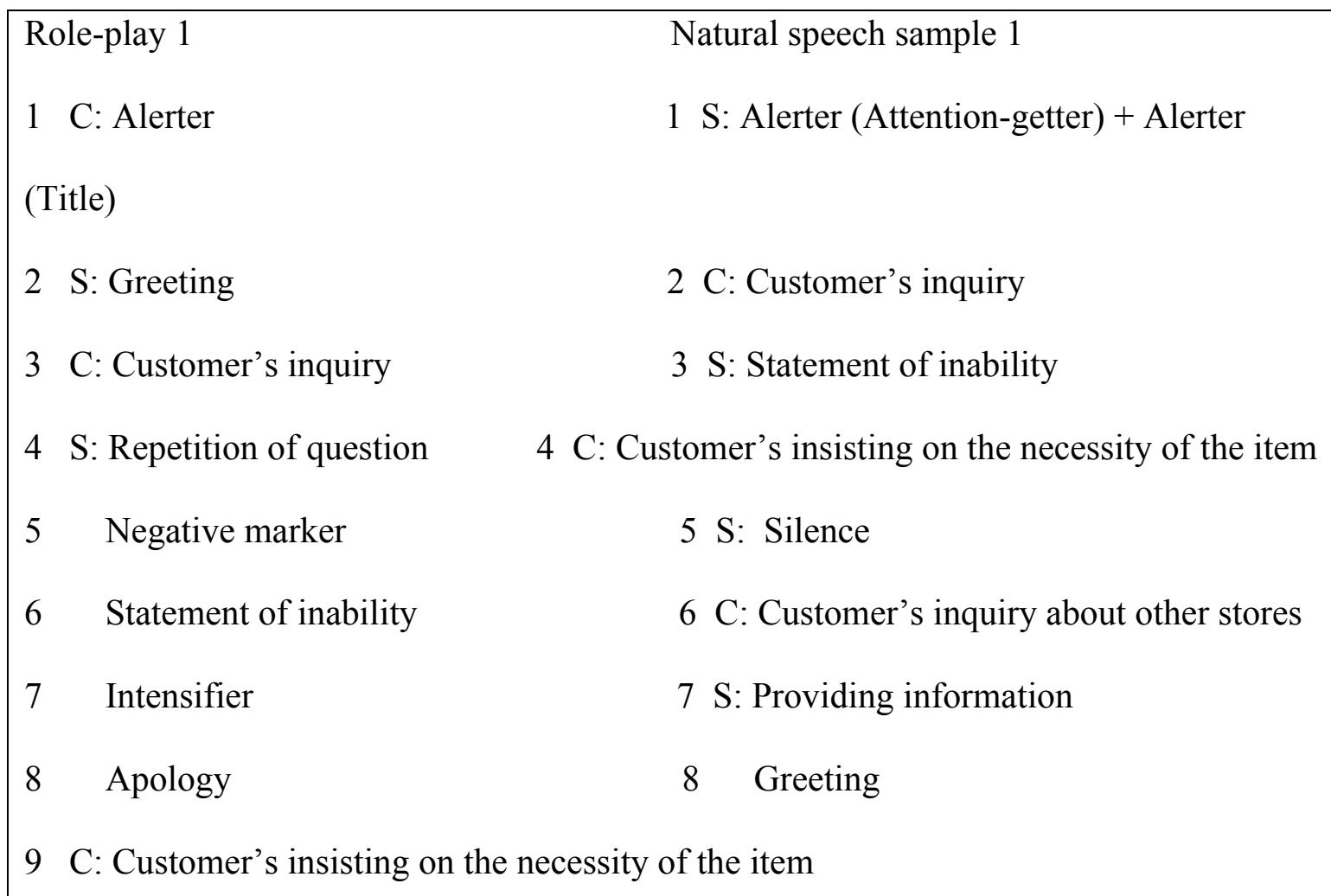




\begin{tabular}{|c|c|}
\hline 11 & Negative marker \\
\hline 12 & Negative marker \\
\hline 13 & Modal \\
\hline 14 & Suggestion \\
\hline 15 & Negative marker \\
\hline 16 & Avoidance \\
\hline 17 & Providing information \\
\hline 18 & Modal \\
\hline 19 & C: Customer's inquiry about other stores \\
\hline 20 & S: Providing information \\
\hline 21 & Modal \\
\hline 22 & Providing information \\
\hline 23 & Intensifier \\
\hline 24 & C: Customer's inquiry about other stores \\
\hline 25 & $\mathrm{~S}$ : Negative marker \\
\hline 26 & Negative marker \\
\hline 27 & Avoidance \\
\hline 28 & Intensifier \\
\hline 29 & Negative marker \\
\hline 30 & Suggestion \\
\hline 31 & Intensifier \\
\hline
\end{tabular}


$32 \mathrm{C}$ : Gratitude

In the Japanese data, although many sales clerks suggested alternative items or used only negative marker or avoidance instead of using statement of inability in natural speech sample, all participants of role-play explicitly expressed her/his inability. On the other hand, in the U.S., role-play data demonstrated that various use of semantic formulas and its sequence is astonishingly longer than natural speech sample. Moreover, the U.S. sales clerks tended to make statements of inability without adjacently having a modal or negative marker in the natural speech sample. In role-play, participants positively used them in the interactions.

- The reliability of coding

Subsequent to a recording of the open-ended role-play, I asked a graduate student (second rater), who is a native speaker of Japanese, to code some speech samples by semantic formulas to verify the reliability of my coding. There were some gaps between researcher's coding and second rater's coding because some semantic formulas such as cajoler and intensifier were excluded from coding by either the researcher or the second rater. Thus, I discarded the semantic formulas that were not coded by both the researcher and the second rater. As a result, the majority of the coding matched despite the fact that there were extra semantic formulas that ended up being coded. This result ensures the accuracy of the researcher's coding not only for the role-play but also for the natural speech sample. 
$\underline{\text { Summary of the results: research questions and hypotheses }}$

Q1. How do sales clerks inform a customer of his/her inability to accommodate a customer's need in Japan and the U.S.?

H1. The statement of inability will occur explicitly in the U.S. On the other hand, Japanese sales clerks will implicitly demonstrate their inability.

Hypothesis 1 has been proven.

Q2. How do sales clerks provide alternative options or facilitate information to achieve the customer's wants to compensate for his/her inability to meet customer's need in Japan and the U.S.?

H2. Sales clerks both in Japan and the U.S. will spontaneously provide alternative items or information that might facilitate meeting the customer's needs as a compensation for his/her inability.

Hypothesis 2 has been proven in Japan, whereas in the U.S., it has been disproven. Q3. How do sales clerks react to the second utterance of a customer to compensate for his/her inability to accommodate a customers' need in service encounters in Japan and the U.S.?

H3. Sales clerks in both the Japan and the U.S. will provide information after the second utterance of a customer.

Hypothesis 3 has been proven from the Japanese data; however, it was disproven from the U.S. data. 
Q4. To what extent and by what means is politeness conveyed through verbal communication in Japan and the U.S. when a sales clerk compensates his/her inability in service encounters?

H4. Since not being able to accommodate a customer's needs is a face-threatening act, a sales clerk will generate utterances that demonstrate his/her politeness both in Japan and the U.S. However, Japanese sales clerks show more politeness expression than U.S. sales clerks.

The occurrences of modal and silence demonstrate a speaker's politeness according to Brown and Levinson (1987), and the use of modal and silence was more frequently used in Japan than the U.S.

Hypothesis 4 was proven for the Japanese sales clerk; however, it was disproven in terms of the U.S.

Q5. Does the sequence of language behaviors observed in natural settings resemble the sequence in oral role-play?

H5. According to Blum-Kulka et al. (1989), the role-playing is reliable data; therefore, the order of semantic formulas of natural oral data and role-playing will be analogous. Data will also indicate that more semantic formulas are used in role-playing than in natural oral data because previous research shows participants' disposition to act their ideal role in role-playing. Hypothesis 5 is proven. 


\section{CHAPTER 5}

\section{Discussion}

In this chapter, I discuss the language behaviors observed in the natural speech samples, and explain the mechanism of compensation in service encounters. As the results show, sales clerks in the U.S. explicitly stated their inability to accommodate a customer's need, whereas Japanese sales clerks tended to avoid directly conveying their inability. Moreover, when the customer insisted on the necessity of the item, some sales clerks in Japan provided information about nearby stores that might carry the product, while most of the U.S. sales clerks simply answered "no." Why were responses different between two countries even though the data was collected in the exact same type of retail store, i.e., a convenience store? What kinds of socio-cultural factors can be attributed to this result? In order to uncover the mechanism of compensation, the set of natural oral samples was analyzed from four aspects: an adjacency pair (Sacks \& Schegloff, 2006), the characteristics of an institutional talk (Drew \& Heritage, 1992), the cooperative principles (Grice, 1975) and a face-threatening act (Brown \& Levinson, 1987), In addition to those analyses, I also compare the data from a natural setting and role-play.

\section{Adjacency pair}

Japanese sales clerks and the U.S. sales clerks uttered differently when they responded to a customer's first inquiry, “ Do you carry blue cheese?” and customer's insisting on the necessity of the item, "I really need one for my recipe tonight." First, I analyze the correlation between the first inquiry of the customer and the response of a sales clerk by comparing the result in Japan and the U.S. and then, I examine the 
relationship between the second utterance of the customer and sales clerk's response by utilizing the same method as the first analysis.

In order to examine the structural relationship between a customer's utterance and a sales clerk's response, I apply the notion of the adjacency pair introduced by Sacks and Schegloff (2006). According to Sacks and Schegloff (2006) an adjacency pair contains two utterances in length, appearing adjacently, and to be produced by different speakers (2006, p. 264). The examples of an adjacency pair, which are termed as "pair type" by Sacks and Schegloff (2006) are question and answer, offer and acceptance or refusal, and so forth. Adjacency pairs were observed in the natural speech sample in this study. However, its occurrence in the U.S. was more frequent than in Japan. The highlighted parts indicate the sequence of semantic formulas following the sales clerk's first inquiry. In the U.S.

C: Customer, S: Sales clerk
Speech sample 2
$1 \quad$ Q1 C: Customer's inquiry
2 A1 S: Statement of inability
3 C: Customer's insisting on the necessity of the item
4 S: Providing information
$5 \quad$ Greeting 
In Japan

C: Customer, S: Sales clerk

Speech sample 1
1 Q1 C: Customer's inquiry
2 S: Negative marker + Providing alternative item
$3 \quad$ C: Customer's insisting on the necessity of the item
$4 \quad$ S: Providing Information
5

Speech sample 3

1 Q1 C: Customer's inquiry

2 S: Repetition of question

$3 \quad$ Negative marker 


\begin{tabular}{|ll|}
\hline 4 & Avoidance \\
5 & Providing alternative item \\
6 & C: Customer's insisting on the necessity of the item \\
7 & S: Silence \\
8 & C: Customer's inquiry about other stores \\
9 & S: Suggestion \\
10 & Gratitude \\
\hline
\end{tabular}

Considering the characteristics of adjacency pair, one might assume that sales clerks would utter "yes" or "no" when a customer asks for a product because those are grammatically appropriate answers to the customer's inquiry. In the U.S., statements of inability were explicitly uttered. Thus, the relationship between the customer's first inquiry and following the sales clerks' utterance in the speech sample was a "questionanswer" pair. On the other hand, in Japan, different semantic formulas were observed instead of a statement of inability. In both speech samples 1 and 3, providing alternative items occurred even though it is grammatically incoherent.

These phenomena are related to Merritt's study in service encounters (1976). Merritt develops the concept of the adjacency pair proposed by Sacks and Schegloff (2006). Merritt explains that an adjacency pair is not a purely linguistic unit, rather, it is a unit of verbal behavior (1976, p. 328). Merritt (1976) also proposes the concept of pragmatic interpretation. Pragmatic interpretation refers to addressee's interpretation of the speaker's utterance generated by considering cultural norms and the context in which 
the speaker and the addressee are engaged. Cultural norms influence the addressee's perception of the speaker's implication in his/her discourse because cultural norms are created by the participant's experience. The possibility of appropriate interpretation is limited by cultural norms. Merritt (1976) also explains three conceptual notions: the rule of maximal appropriateness, contextual presupposition, and response that provide an answer (p. 346). When a speaker utters, the speaker's first utterance allows an addressee to presuppose the context. The addressee intends to perceive what context he/she is engaged in, and then interprets the speaker's utterance, more than its referential meaning, including the conventional meaning. And then the addressee utters by maximizing the appropriateness in the context. Furthermore, when a speaker asks something, the speaker also presupposes the response will be the answer. Taking all aspects into account, it is fair to assume that the U.S. sales clerk interpreted the customer's utterance as a simple inquiry about the product, whereas Japanese sales clerks interpreted that the customer's utterance was not just an inquiry about carrying the product at the store. Therefore, since the store did not carry the product, Japanese sales clerks assumed that providing alternative items can inform their inability and might be expected by the customer from his/her experience. This is one method of compensation for the inability of the customer's need in Japan. In relation to this, even though the Japanese speech sample did not demonstrate an adjacency pair, the sales clerk's response was pragmatically coherent, and the customer also presupposed that it must be the answer. Thus, the customer perceived what "providing alternative item" implied based on her social norm in service encounters. 
On the other hand, regarding the relationship between the "customer's insisting on the necessity of the item" and following semantic formulas, the occurrence of semantic formulas varied in both Japan and the U.S. In Japan, "providing information," "silence," and "avoidance" occurred. In the U.S., "providing information," "silence," and "statement of inability" were observed. Since the "customer's insisting on the necessity of the item" is merely statement, there is no specific response required. Namely, there is no expected adjacency pair in this segment. In fact, "silence" and "providing information" occurred in both Japan and the United States. However, the "statement of inability" only occurred in the U.S., and the other semantic formulas such as "avoidance" and "negative marker" were only used in Japan. The following are examples: In Japan
Speech sample 1
1 C: Customer's inquiry
2 S: Negative marker + Providing alternative items
3 C: Customer's insisting the necessity of the item
4 S: Providing Information
Gratitude
Speech sample 3
1 C: Customer's inquiry
2 S: Repetition of question
$3 \quad$ Negative marker 


\begin{tabular}{|ll}
\hline 4 & Avoidance \\
5 & Providing alternative item \\
6 & C: Customer's insisting the necessity of the item \\
7 & S: Silence \\
8 & C: Customer's inquiry about other stores \\
9 & S: Suggestion \\
10 & Gratitude
\end{tabular}

\begin{tabular}{|ll}
\hline $\begin{array}{l}\text { Speech sample } 9 \\
1\end{array}$ & C: Customer's inquiry \\
2 & S: Avoidance \\
3 & Statement of inability \\
4 & C: Customer's insisting the necessity of the item \\
5 & Avoidance \\
6 & C: Customer's inquiry about other stores \\
7 & S: Providing information (reluctantly)
\end{tabular}

In the U.S.

Speech sample 2
$1 \quad$ C: Customer's inquiry
$2 \quad$ S: Statement of inability
$3 \quad$ C: Customer's insisting the necessity of the item 
$\begin{array}{lc}4 & \text { S: Providing information } \\ 5 & \text { Greeting }\end{array}$

Speech sample 4

1 C: Customer's inquiry

2 S: Statement of inability

3 C: Customer's insisting the necessity of the item

$4 \quad$ S: Silence

5 C: Customer's inquiry about other stores

6 S: Providing information

$7 \quad$ Greeting
Speech sample 5
1 C: Customer's inquiry
2 S: Statement of inability
3 Apology
$4 \quad$ C: Customer's insisting the necessity of the item
5 S: Statement of inability
6 C: Customer's inquiry about other stores
7 S: Providing information + Modal 
According to the speech samples, although a customer's second utterance was a statement, not a question, sales clerks in Japan and the U.S. provided information. These two utterances are not an adjacency pair. However, as well as the previous analysis, sales clerks interpreted the statement as a request for further information that allows a customer to obtain the product. Furthermore, the occurrence of "statement of inability" in the United States and "negative marker" or "avoidance" in Japan emerges from the sales clerks' interpretation of customer's statement. What allows sales clerks to appropriately interpret the customer's statement is related to the characteristics of talk in service encounters?

$\underline{\text { Institutional Talk }}$

Merritt (1976) illustrates the appropriateness of participants' utterances in human interaction, in other words, which refers to "the function of context" (p. 346). The shared context between a speaker and an addressee always governs the shared discourse. The sales clerks pursue ensuring the appropriateness in his/her utterance by interpreting the speaker's intention appropriately. In this study, although natural speech samples were collected in service encounters in both Japan and the U.S., Japanese sales clerks and U.S. sales clerks interpreted a customer's utterance differently. Why were there such differences between Japan and the U.S.? What allows the sales clerks to evaluate the appropriateness of their language behavior? How did sales clerks perceive the expectation from the customer? These queries are associated with the characteristics of discourse produced in service encounters, which is considered to be institutional talk, coined by Drew and Heritage (1992). Drew and Heritage (1992) defined "institutional 
talk" as a talk that occurs in the institutions which participants have a professional role and its talk is constrained by the role in the institution (1992, p. 3-4). In institutional talk, participants have a certain task or goal to achieve what is conventionally related to the institution in which the participants were involved. The institutional interaction constrains one or both participant's discourse because participants pursue their role to make a contribution to the business. Moreover, institutional talk is related to inferential frame works and procedures specialized by institutional context (Drew \& Heritage, 1992, p 22-25).

In this study, both participants, a customer and a sales clerk, have a goal: obtaining blue cheese for the customer, and for the sales clerk, selling or maybe facilitating the customer to get blue cheese. Thus, sales clerks consider the way of contributing to the customer's need by producing appropriate utterance for his/her professional role. Even though the goal is the same, the social norm for service encounter was different in Japan and the U.S. Therefore, the customer's expectation about the sales clerk's job/role is different in Japan and the U.S., and that causes different reactions in customer's utterances. When the customer inquired about carrying blue cheese, most Japanese sales clerks suggested alternative items, while U.S. sales clerks mainly stated their inability. These results attribute to how sales clerks perceive the way of maximizing his/her contribution to achieve a customer's goal, i.e., obtaining blue cheese, in each country. In Japan, it is possible to regard that social expectation in service encounters inclined sales clerks to provide alternative items instead of stating the inability because that is contributive to the customer rather than stating the inability. On the other hand, in 
the U.S., it is possible to assume that explicitly demonstrating an inability contributes best for a customer, and sales clerks are not really expected to do anything more than that is asked in service encounters, especially in a convenience store. Thus, such social norms disposed sales clerks in the U.S. to state their inability.

In terms of sales clerks' reactions to the customer's second utterance, a “customer's insisting on the necessity of the item," both Japanese and the U.S. sales clerks provided the information about other stores. In this case, it is legitimate to consider that the sales clerks in both Japan and the U.S. shared the same perception about what the customer really meant. Since the customer insisted on the necessity of the item even though she knew the store did not carry the product, the customer's statement prompts them to think what response is appropriate in a service encounter, and they reached the interpretation that "providing information" may be expected or be contributive to the customer.

In sum, the different interpretation of customer's utterance between Japan and the U.S. attributes to sales clerks' social norm in service encounters, which influences their language behavior to make a contribution to achieve a customer's goal. An institutional context allows sales clerks to evaluate the appropriateness of his/her utterance and also what social norm is applicable. By means of regarding his/her knowledge, experience, and the expectation from a customer, sales clerks utter appropriately. Thus, differing social norms in institutional interaction is the significant factor of different language behaviors of sales clerks in Japan and the U.S. 


\section{Cooperative principle}

In institutional talk, participants' utterances are constrained by an institutional context because participants' roles require them to render/perform appropriate utterance to contribute to one another in business. When a speaker utters, an addressee strives to perceive a speaker's expectation to maximize her/his contribution to the speaker. Simultaneously, the speaker intends to interpret the addressee's intention appropriately by means of considering the context in which they are engaged. Thus, even if the intention is implicitly exhibited, both a speaker and an addressee terminate their exchanges successfully because they cooperate to reach the goal of the conversation by utilizing a shared context. Grice (1975) explains such mechanism in a human interaction. According to Grice (1975), a successful exchange is achieved by participants' cooperative effort based on the cooperative principle in terms of quantity, quality, relation, and manner (Grice, 1975, p. 45-47). This cooperative principle is one of the clues to discover why different language behaviors of sales clerks occurred in Japan and the U. S. in this study.

When the customer asked for the product, Japanese sales clerks provided the information of alternative items instead of a statement of inability, and the U.S. sales clerks stated their inability. According to Grice (1975), "quantity" refers to "make your contribution as informative as is required (for the current purposes of exchange)" and "do not make your contribution more informative than is required" (p.45). Sales clerks in both Japan and the U.S. attempted to make their contribution to a customer by satisfying the aspect of "quantity." In this study, the customer's goal is to obtain the product, and 
the sales clerk's goal is to provide the product or facilitate the customer to achieve her goal. Since the store does not carry blue cheese, it is possible to assume that Japanese sales clerks perceive that the customer expects the information about other cheese. Thus, Japanese sales clerks respond to a customer with required information: a replacement for blue cheese.

As opposed to Japanese sales clerks, U.S. sales clerks probably consider that it is unnecessary to provide any information related to cheese since a customer only asked about the availability of blue cheese. Responding to the customer with a "statement of inability" is informative enough to make a contribution according to their knowledge of service encounter. Since the norm of service encounter is different between Japan and the U.S., sale clerks' response was different, yet the response meets Grice's “quantity" respectively. The characteristic of U.S. sales clerks' response is also associated with Grice's “manner” (1975, P.46). "Manner" means to "avoid obscurity of expression," "avoid ambiguity," "be brief (avoid unnecessary prolixity), and "be orderly" (1975, p.46). Demonstrating a "statement of inability" is an explicit utterance to inform their inability; thus, a sales clerk applies this principle to contribute to a customer. Furthermore, the sales clerks both in Japan and the U.S. demonstrated a "relation" that illustrates how a speaker makes an immediate contribution to the addressee's need. Even though actual utterances observed in Japan and the U.S. were different, sales clerk's utterances inform the customer that their store does not carry blue cheese, or carries only other types of cheese. That is the necessary information for the customer to achieve his/her purpose in the store-obtaining blue cheese, otherwise finding the way to purchase blue cheese. 
Thus, sales clerks' utterances both in Japan and the U.S. are relevant to the customer's need.

In addition, "quantity" was also used after the second utterance of a customer: the "customer's insisting on the necessity of the item." The sales clerks both in Japan and the U.S. provided information about other stores. Although the customer's utterance was a statement, sales clerks perceive that the customer needs some information from him/her to get blue cheese; in other words, it is required by the customer according to his/her norm in the service encounter. Therefore, by means of providing information of other stores that might carry blue cheese, sales clerks contributed to the customer's need because receiving such information allows the customer to find blue cheese at least.

Consequently, there are the strategies for sales clerks to contribute to the customer, which utilize Grice's (1975) cooperative principle, especially "quantity," "relation," and "manner." Sales clerks evaluate what kind of behaviors can be beneficial for a customer by means of interpreting a customer's utterance including what is inferred as well as what is explicitly mentioned. In the process of the evaluation, sales clerks consider the method of conveying the information to the customer, and its contents or the amount varies in Japan and the U.S. Simultaneously, a customer also attempts to interpret what a sales clerk's utterance actually means. By means of cooperative effort of a customer and sales clerks, they can achieve their own goal, the one determined by their role in service encounter. 
Face-threatening acts (Compensation efforts)

In previous analysis, it is significant that the differences of social norms in a service encounter influence the interpretation of expectation among participants. However, what kind of psychological features besides social expectation elicit sales clerk's utterance is still unrevealed. What makes Japanese sales clerks provide alternative items instead of stating his/her inability when a customer asked the availability of blue cheese in a store? What restrains Japanese sales clerks from explicitly stating his/her inability? Some sales clerks used several semantic formulas after customer's inquiry about the product, and none of them really demonstrated their inability of accommodating customer's need. On the other hand, what allows U.S. sales clerks directly inform the customer their inability? These questions closely correlate with the maintenance of the face of both customers and sales clerks. As mentioned in the review of literature, according to Brown and Levinson (1987), human beings have two different types of faces, positive face and negative face. In human interaction, participants strive to maintain their own and others' face by means of tactfully using language. Moreover, the strategies of maintenance of the two faces, redressing from a face-threatening act, and causing a face-threatening act vary in different cultures.

In this study, the customer's inquiry about the product that the store does not carry blue cheese is a face-threatening act, because the utterance forces sales clerks to inform a customer of their inability to provide the item and that sequentially violates sales clerk's positive face: wanting to be liked. Simultaneously, informing the inability to a customer is also a face-threatening act because it violates the customer's negative face; 
her wants need to be unimpeded. In this section, I examine how the maintenance of face influences sales clerks' attitude of informing their inability to a customer in the situation of not being able to accommodate the customer's need, and uncover the mechanism of compensation in service encounters.

- The length of discourse

First, I compare the sequence of semantic formulas and explore how particular semantic formulas were used between Japan and the U.S. Examining the category of semantic formulas used in the interactions and its length allows us to approach sales clerks' politeness strategies.

The natural speech samples demonstrated that Japanese sales clerks rarely stated their inability to respond to a customer's inquiry; instead, many of them provided alternative items or some sales clerks did not even explicitly mention that they do not carry blue cheese. Those sales clerks consecutively used several semantic formulas. Even the sales clerks who provided alternative items demonstrated the sequence of several semantic formulas preceding their providing alternative items. On the other hand, many U.S. sales clerks explicitly stated their inability as a response. Because of such different language behaviors between Japan and the U.S., the length of the sequence of semantic formulas was different between Japan and the U.S.; Japanese semantic formulas were longer than the U.S. semantic formulas. The following are the Japanese examples that demonstrate relatively long sequences of semantic formulas after customer's inquiry about blue cheese. 
In Japan

\begin{tabular}{|ll}
\hline $\begin{array}{l}\text { Speech sample } 3 \\
1\end{array}$ & C: Customer's inquiry \\
3 & S: Repetition of question \\
4 & Negative marker \\
5 & Avoidance \\
6 & C: Customer's insisting on the necessity of the item \\
7 & S: Silence \\
8 & C: Customer's inquiry about other stores \\
9 & S: Suggestion \\
10 & Gratitude
\end{tabular}

In the U.S.

Speech sample1
$1 \quad$ S: Alerter (attention-getter) + Alerter (Title)
$2 \quad$ C: Customer's inquiry
$3 \quad$ S: Statement of inability
$4 \quad$ C: Customer's insisting on the necessity of the item
$5 \quad$ S: Confirm with another co-worker
$6 \quad$ Silence
7


$\begin{array}{lc}8 & \text { S: Providing information } \\ 9 & \text { Greeting }\end{array}$

The Japanese examples above show that semantic formulas such as "negative marker" and "avoidance” preceded sales clerks' providing alternative items, and simultaneously those sales clerks did not demonstrate a "statement of inability." It is possible to interpret such sales clerks' language behaviors as gaining time in order to maintain their positive face until the customer perceives their inability to provide a requested product. By means of using several semantic formulas, sales clerks can postpone stating their inability that potentially violates the customer's negative face, and also the sales clerk's positive face. Thus, the use of several semantic formulas serves the purpose of lessening face damage. This behavior also represents "off-record" according to Brown and Levinson's possible strategies for doing FTAs (1987, p. 69). According to them, "Off-record" refers to the speaker's language behaviors that indirectly convey his/her intention without seriously damaging his/her or the addressee's face. By means of going "off-record," the speaker can minimize his/her risk to damage the addressee's face, and also can be less responsible for the damage $(1987$, p. 69,71$)$. Thus, the sequence of semantic formulas observed in Japanese natural speech sample represents sales clerks' effort to diminish face damage.

On the other hand, in the U.S., the length of the sequence of semantic formulas is much shorter than Japanese ones because the "statement of inability" tended to immediately follow the customer's inquiry. This is the direct message of not being able to 
accommodate the customer's need, and also this language behavior is considered to be “on-record,” as termed by Brown and Levinson (1987, p. 69, 71). “On-record” represents speaker's explicit expression of his/her intention (Brown \& Levinson, 1987, p. 69, 71). Brown and Levinson categorized the act of "on-record" into two acts — without redressive action or with redressive action. The former refers to the bold presentation of the speaker's communicative intention to an addressee, and the latter represents the act that mitigates potential face damage (1987, p. 69). Thus, the U.S. sales clerks' demonstration of a "statement of inability" is considered to be "on-record without redressive action." Brown and Levinson (1987) also mention that "normally, an FTA will be done in this way only if the speaker does not fear retribution from the addressee" (1987, p. 69). For example, in the case of service encounters, when both a sales clerk and a customer accept the fact that the face demand was legitimately delayed to respect the efficiency of the conversation between them, the degree of face damage of a customer is small because knowing the possibility of obtaining the product is the center of customer's interest in this situation. Hence, a sales clerk does not sacrifice his/her face and the customer's face entirely, and going "on-record" ascribes to such a profit in the U.S.

Additionally, Brown and Levinson (1987) explain "payoffs" that refer to the profits generated by being off-record or on-record. According to Brown and Levinson (1987), off-record payoffs include the following (p. 73):

Off-record payoffs:

(a) S can satisfy negative face to a degree greater than that afforded by the negative-politeness strategy.

(b) S can avoid the inescapable accountability, the responsibility for his action, that on-record strategies entail. 
Japanese sales clerks demonstrated the payoffs above. By providing alternative items, instead of saying “no," sales clerks could diminish damaging a customer's negative face. Moreover, informing the customer of their inability by saying "no" is considered to be an on-record strategy, and a sales clerk has a responsibility to inform his/her inability to a customer; however, he/she can avoid doing so by providing an alternative item. Furthermore, Brown and Levinson (1987) also mention on-record payoffs as follows (p. 72):

On-record payoffs:

(a) clarity, perspicuousness

(b) demonstrable non-manipulativeness

Bald-on-record (non-redressed) payoff:

efficiency (S can claim that other things are more important than face, or that the act is not an FTA at all)

The U.S. sales clerks exhibit on-record pay-off strategies. In contrast to Japanese sales clerks, U.S. sales clerks clearly stated "no;" thus, there was no manipulative language behavior. Moreover, an explicit statement of inability seems to be employed in the interest of aiding efficiency of interaction in service encounters in the U.S. Most sales clerks responded to a customer by saying "no," and that response also succinctly informs a customer of his/her inability to provide blue cheese in the store. Thus, saying "no" may not be even considered as a face-threatening act for a customer since a customer also expects efficient termination of their conversation in the U.S.

Consequently, there are two different phases to cause a face-threatening act between Japan and the U.S. By applying Brown and Levinson's possible strategies for doing FTAs (1987, p. 69), Japanese sales clerks tend to go "off-record," whereas the U.S. 
sales clerks tend to go "on-record." In other words, Japanese sales clerks attempt to minimize face damage and maintain their face and the customer's face by implicitly conveying their inability, while sales clerks in the U.S. explicitly inform the other of their inability. It is possible to conclude that such differences ascribe to the differences of cultural expectation in Japan and the U.S. As natural oral samples showed, diminishing face-damage is significant in Japan; however, efficiency can be a priority in the U.S. Thus, when sales clerks perceive that they have to cause a face- threatening act, i.e., informing a customer of their inability to provide blue cheese, Japanese sales clerks and the U.S. clerks acted differently, yet both acts are appropriate in their culture respectively. - Politeness expressions (the use of modals \& silence)

In relation to politeness, the sales clerks of both Japan and the U.S. used modals and silence, which is considered to be an expression of politeness according to Brown and Levinson (1987). "Silence” mainly occurred following the customer's second utterance, "customer's insisting on the necessity of the item," and a "modal" coincided with sales clerks' "providing information" following customer's second utterance or the third utterance "customer's inquiry about other stores."

In terms of "silence," Brown and Levinson (1987) explain that deliberate silence as a response is the politest refusal because answering by saying something causes face damage in any case; not saying anything allows a speaker to minimize face damage (p. 295). Sales clerks demonstrated silence in both Japan and the U.S., though Japanese sales clerks used silence more frequently than the U.S. sales clerks. Since sales clerks remained silent when a customer insisted on the necessity of blue cheese, it is possible to surmise 
that sales clerks were perplexed with the customer's utterance. However, as Brown and Levinson (1987) mention, "silence" is also interpreted as a sales clerks' attempt not to cause any face-threatening act. Moreover, the number of sales clerks who used "silence" indicates that Japanese sales clerks tend more to avoid a direct face-threatening act than the U.S. sales clerks.

As far as "modals" are concerned, "modals," such as "might" and "could," function as an impersonalization of the speaker's utterance. According to Brown and Levinson (1987), the subject "it" tends to be used in modal expressions; thus, the speaker's utterance is conveyed objectively to an addressee as if the speaker is not directly causing a face-threatening act. Therefore, the use of a modal exhibits the speaker's effort to minimize face damage, namely the representation of politeness. Modal verbs coincided with providing information of other stores in both Japan and the U.S. The result showed that the majority of Japanese sales clerks used modals, whereas only one sales clerk used a modal in the U.S. Those phenomena indicate that Japanese sales clerks are more concerned about lessening face damage. Although sales clerks provide information about other stores that could help a customer to find blue cheese, they are still unsure if the store carries blue cheese. Using modal verbs allow sales clerks to show their uncertainty of the information, and that prevents sales clerks from being accountable for the information. In other words, this behavior exhibits sales clerks' maintenance of their own positive face and a customer's negative face. Since Japanese sales clerks demonstrated more frequent use of modals than U.S. sale clerks, Japanese sales clerks tend to emphasize minimization of face damage more than the United States sales clerks. 
- Compensation effort

Being unable to accommodate a customer's need jeopardizes sales clerks' desire not to cause a face-threatening act. In this situation, any verbal or non-verbal response to a customer's inquiry causes a face-threatening act. However, as a sales clerk, it is inevitable not to respond to a customer's inquiry; thus, sales clerks elaborate their utterance or compensate for their face-threatening act somehow. There is the mechanism of compensation in Japan, while there is no prominent compensation activity employed by the U.S. sales clerks.

In Japan, compensation activity begins as an avoidance of directly causing a facethreatening act. When a customer asked for blue cheese, Japanese sales clerks provided alternative items instead of stating their inability, and that allows Japanese sales clerks to simultaneously minimize their face-threatening act because this conveys their inability indirectly. Furthermore, Japanese sales clerks also provide information about other stores without being explicitly asked; that occurred when a customer insisted on the necessity of blue cheese. Although a customer's utterance is a statement, i.e., the customer did not exactly ask for the information about other stores, sales clerks presuppose that the information can contribute to a customer's satisfaction, and that ultimately compensates for their inability to accommodate a customer's need. Japanese sales clerks also utilized some politeness expressions in the process of compensation, such as a modals and silence. Japanese sales clerks compensate for their inability by spontaneously providing alternative items or information about other stores with consistent caution about diminishing their face-threatening act. 
On the other hand, the U.S. sales clerks studied rarely compensated for their inability. Most of sales clerks responded to a customer with an explicit statement of inability. Only a few sales clerks provided the information about other stores when a customer insisted on the necessity of blue cheese or directly inquired about other stores. However, the majority of sales clerks state their inability consistently. In terms of use of politeness expression, the U.S. sales clerks do not use them as frequently as Japanese sale clerks. Therefore, the U.S. sales clerks neither compensate for the inability, nor strive to minimize face damage.

As previously mentioned, sales clerks' different strategies for causing a facethreatening act attribute to different expectations in service encounters in Japan and the U.S. In service encounters, a customer and a sales clerk have certain roles respectively; thus, the role governs their language behavior because the context, service encounter, allows both a customer and a sales clerk to perceive what is expected by one another. In Japan, failing to satisfy a customer's need is a crisis as a sales clerk. Additionally the maintenance of the face of the store is important. Therefore, Japanese sales clerks attempt to compensate for their inability while minimizing face damage by providing information that they perceive is helpful for a customer. However, in the U.S., efficiency seems to be expected in exchanges in service encounters. Thus, a sales clerk perceives that clearly informing their inability is helpful for a customer, and even his/her utterance may not be considered as a face-threatening act in this situation; namely, there is no need for compensation. 
Natural speech sample and Role-play

In this study, I collected data in two different approaches: natural speech sample and role-play. In order to ensure the naturalness of sales clerks' utterances, natural speech samples were coded by semantic formulas; namely, no recording devise was used. Since all records of natural speech samples only show the sequence of semantic formulas, it is difficult to recall what sales clerk actually uttered after the data collection. Although previous studies on speech acts tend to use role-play to discover the process of achievement of a speech act, many researchers claim the number of language behaviors we can discover from role-play data is limited and even those results may be unreliable. Since participants of role-play have to agree to being recorded during a role-play, there is the tendency for participants to play their ideal act in a given context, and ultimately that prevents a researcher from collecting data that demonstrates how people actually act.

In fact, the length of the sequences of semantic formulas was different between natural speech samples and role-plays in both Japan and the U.S. The length of natural speech samples was much shorter than role-play speech samples. That explains why participants tend to talk more than actual sales clerks. In terms of the semantic formulas used by participants of role-play, there is more use of "avoidance," "negative markers" and "modals" than natural speech samples. This is one of the reasons why the role-plays' length was longer than natural speech samples. However, the sequence of semantic formulas in role-play was very similar to natural speech samples. Therefore, the data from role-play at least facilitates the researcher to visualize the situation and what sales clerks actually uttered in a natural setting. 
Furthermore, sales clerks in Japan and the U.S. generated different characteristics of language behavior in role-play from natural speech sample. In Japanese, in the natural speech sample, most of the sale clerks provided alternative items or just used "avoidance" or "negative markers" instead of using a statement of inability. However, in role-play, all participants stated their inability as a response to the customer's inquiry about blue cheese. This can be accounted for by the situational explanation that participants read before recording. The situation card states, "One day, a customer comes in and asks you if your convenience store sells/carries blue cheese or not. Your convenience store does not sell/carry blue cheese," (see appendix G) in order for the researcher to obtain data for the compensation. Without the explicit instruction of not carrying blue cheese, a participant might say, "Yes, we do have blue cheese." In addition, role-play participants might be circumspect in role-playing a sales clerk, because they know what kind of interaction it will be due to the situation card. On the other hand, for sales clerks actually working for convenience stores, the customer's inquiry about blue cheese is unexpected. Thus, natural speech samples demonstrate sales clerks' instant reaction to a customer, whereas role-play exhibits deliberate speech. Therefore, the situational explanation for role-play affects participant's language behaviors and sometimes incurs unauthentic discourse.

In terms of role-play in the U.S., participants demonstrated more frequent "negative markers," "avoidance," "modals" and long explanations for other stores, and those phenomena were rarely observed in the natural speech sample. This exhibits participants' carefulness in generating their utterance, and hesitation, etc. as opposed to 
natural speech samples that aimed for the efficacy of conversation in a convenience store. The frequent use of a variety of semantic formulas in role-play seems to represent participants' unconscious effort to act as an ideal sales clerk based on their experience. Thus, the role-play recorded in the U.S. was not inauthentic.

Overall, the comparison of data between a natural speech sample and role-play suggests the importance of obtaining discourse data in a natural setting. Although it is still possible to reveal some strategies of achieving a speech act from role-play, as long as participants know their speech is recorded, it is impossible for them to ignore the fact that they are being recorded, and to overact their required roles in a role-play. However, the order of semantic formulas was similar, even though there are major differences in the length of discourse between natural speech sample and a role-play. Thus, data from roleplays allow us to recall what sales clerks in convenience stores uttered during data collection, and supplement natural speech sample. 


\section{CHAPTER 6}

\section{Conclusion}

Overview of major findings of this study

This study aims to uncover the mechanism of compensation for an inability to meet a customer's need in a service encounter in different cultures. Whether or not a sales clerk compensates for his/her inability is contingent upon sales clerk's perception of the degree of a face-threatening act, and the evaluation of the degree is according to social norms in the service encounter that the sales clerk established through his/her life experience. Since social norms differ in each culture, sales clerks demonstrated different language behaviors in Japan and the U.S.

Japanese sales clerks strive to minimize face damage by implicitly conveying the unavailability of blue cheese in the store with "negative marker," "avoidance," "providing information" and so forth. These linguistic and nonlinguistic elements are also illocutionary acts of negation.

Japanese sales clerks also tend to provide the information about other stores spontaneously to maximize their capability of being a sales clerk. According to Japanese norms, a statement of inability causes a great deal of face damage to sales clerks' positive face and customer's negative face; thus, sales clerks demonstrated language behaviors that diminish face damage and compensate for their inability by providing other helpful information.

On the other hand, in the U.S., most of the sales clerks demonstrated explicit statement of inability to customer's inquiry about the product; moreover, the majority of 
sales clerks did not provide information about other stores etc. without being explicitly asked. According to U.S. norms, the talk in convenience store aims for efficacy; therefore, statement of inability does not cause much face damage, and actually satisfies the goal of exchanges in a convenience store. Hence, in the U.S., there was no prominent compensation effort.

When customers ask for a product that the store does not carry, a sales clerk perceives that he/she has to cause a face-threatening act, and then the sales clerk attempts to consider what is expected by a customer or is appropriate in his/her professional role, i.e., a sales clerk, based on the social norm in service encounters. Since the exchanges in service encounters are institutional talk, namely goal-oriented talk, the sales clerk looks for the goal of the interaction and the goal is embodied in sales clerk's utterance. The sales clerk also intends to verbally make a contribution to a customer in business. The sales clerk integrates his/her knowledge in service encounters, and determines the seriousness of informing a customer of his/her inability. That allows him/her to determine the necessity of compensation and to choose the strategies of causing a face-threatening act.

This study illuminates the mechanism of compensation in different cultures, and how norm differences in a certain context govern participants' discourses. Moreover, whether compensation is necessary or not is dependent on the degree of face damage in each culture. Hence, this study underscores the necessity of taking into account cultural norms about the degree of face damage that correlates with social expectations. In addition, the study also stresses discreet analysis of situations in which a participant 
causes a face-threatening act. This study supports the findings of previous studies in terms of the significance of obtaining natural speech sample and the research design to maximize data reliability.

$\underline{\text { Limitations of this study }}$

Lastly, this study has its limitations. The sample size of data, for both natural speech sample and role-play, was too small to make broader generalizations about the mechanisms of compensation. Moreover, since this study focused on the talk in a convenience store within a service encounter setting, it will be necessary to observe how compensation is achieved in different types of stores or other settings. For instance, the expectation of service may be different between convenience stores and department stores. Results might be different depending upon the type of store. Moreover, although I did not obtain any demographic information on the salesclerks in a natural data sample, I have come to realize that sales clerk's experience, age and gender affect whether he/she intended to provide other information spontaneously or not. Thus, these aspects should be taken into consideration in further research. 


\section{References}

Austin, J.L. (1962). How to do things with words. Cambridge: Harvard University Press.

Bardovi-Harling, K. (2001). Pragmatics in language teaching. In K. Rose and G. Kasper (Eds.), Pragmatics in language teaching (pp.13-32). Cambridge: Cambridge University Press.

Blum-Kulka, S., \& House, J., \& Kasper, G. (1989). Cross-cultural pragmatics: Requests and apologies. Norwood, NJ: Ablex Publishing Cooperation.

Brown, P., \& Levinson, S. (1987). Politeness: Some universals in language use. Cambridge: Cambridge University Press.

Byon, A. S. (2004). Sociopragmatic analysis of Korean requests: pedagogical settings. Journal of Pragmatics, 36 (9), 1673-1704.

Drew, P., \& Heritage, J. (1992). Talk at work: interactional settings. Cambridge: Cambridge University Press.

Goffman, E. (2006). Interaction ritual: Essay on face-to-face behavior. In A. Jaworski and N. Coupland (Eds.), The Discourse Reader (pp. 299-310). NewYork, NY: Routledge

Grice, H. P. (1975). Logic and conversation. In Peter, E., \& Morgan, J (Eds.), Syntax and Semantics, 3; Speech Acts (pp.41-58).

Merritt, M. (1976). On questions following questions in service encounters. Language in Society, 5, 315-317.

Sacks, H. \& Schegloff, E, A. (2006). Opening up closings. Semiotica VIII. 289-327. In A. 
Jaworski and N. Coupland (Eds.), Discourse Reader (pp. 299-310). NewYork, NY: Routledge.

Sacks, H., \& Schegloff, E, A., \& Jefferson, G. (1974). A simplest systematics for the organization of turn-taking for conversation. Language 50. 696-735.

Searle, J. R. (1969). Speech Acts. London: Cambridge University Press.

Taira, A. (2008). Refusal and politeness in Japanese as a second language. MA thesis: Portland State University.

Tsuda, A. (1984). Sales talk in Japan and United States. Washington D.C.: Georgetown University Press. 


\section{Appendix A \\ Natural speech sample from convenience stores coded by semantic formulas in Japan and the U.S.}

Appendices

\section{In Japan}

C: Customer S: Sales clerks

Speech sample 1

1 C: Customer's inquiry

2 S: Negative marker + Providing alternative items

$3 \mathrm{C}$ : Customer's insisting on the necessity of the item

4 S: Providing Information

5 Gratitude

Speech sample 2

1 C: Customer's inquiry

2 S: Repetition of question

3 Statement of inability

4 C: Customer's insisting on the necessity of the item

5 S: Confirmation with another co-worker

6 Statement of inability by co-worker

7 C: Customer's inquiry about other stores

8 S: Providing information + Modal

9 Gratitude

Speech sample 3

1 C: Customer's inquiry

2 S: Repetition of question

3 Negative marker

4 Avoidance

5 Providing alternative item

6 C: Customer's insisting on the necessity of the item

7 S: Silence

8 C: Customer's inquiry about other stores

9 S: Suggestion

10 Gratitude

Speech sample 4

1 C: Customer's inquiry

2 S: Repetition of question

3 Negative marker

$4 \quad$ Indicating alternative items

5 C: Customer's insisting on the necessity of the item 
6 S: Providing information + Encouragement

7 Gratitude

Speech sample 5

1 C: Customer's inquiry

2 S: Providing alternative items (check out the shelf)

3 C: Customer's insisting on the necessity of the item

4 S: Repetition of question (blue cheese desu ka...)

5 Providing information + Modal

6 Apology

7 Gratitude

Speech sample 6

1 C: Customer's inquiry

2 S: Repetition of question

(Checking out shelf)

3 Providing alternative items

4 Statement of inability

5 C: Customer's insisting on the necessity of the item

6 S: Providing information + Modal

Speech sample 7

1 C: Customer's inquiry

2 S: Repetition of question

3 Confirm with another co-worker

4 Statement of inability

5 C: Customer's insisting on the necessity of the item

6 S: Silence +Avoidance

Speech sample 8

1 C: Customer's inquiry

2 S: Repetition of question

3 Negative marker

4 C: Customer's insisting on the necessity of the item

5 S: Silence

6 C: Customer's inquiry about other stores

7 S: Providing information + Modal + Modal + Modal

Speech sample 9

1 C: Customer's inquiry

2 S: Avoidance

3 Statement of inability

4 C: Customer's insisting on the necessity of the item

5 Avoidance

6 C: Customer's inquiry about other stores 
7 S: Providing information (reluctantly)

Speech sample 10

1 C: Customer's inquiry

2 S: Avoidance

3 Statement of inability

$4 \mathrm{C}$ : Customer's insisting on the necessity of the item

5 S: Negative marker

6 C: Customer's inquiry about other stores

7 S: Statement of inability

8 Apology

Speech sample 11

1 C: Customer's inquiry

2 S: Repetition of question

3 Avoidance

4 Confirm with co-worker (showing cheese section)

5 C: Customer's insisting on the necessity of the item

6 S: Silence

7 C: Customer's inquiry about other store

8 S: Providing information

9 Gratitude

\section{In the U. S.}

C: Customer S: Sales clerks

Speech sample1

1 S: Alerter (attention-getter)+ Alerter (Title)

2 C: Customer's inquiry

3 S: Statement of inability

4 C: Customer's insisting on the necessity of the item

5 S: Confirm with another co-worker

$6 \quad$ Silence

7 C: Customer's inquiry about other stores

8 S: Providing information

$9 \quad$ Greeting

Speech sample 2

1 C: Customer's inquiry

2 S: Statement of inability

3 C: Customer's insisting on the necessity of the item

4 S: Providing information 
$5 \quad$ Greeting

Speech sample 3

1 C: Customer's inquiry

2 S: Statement of inability

3 C: Customer's insisting on the necessity of the item

4 S: Providing information

Speech sample 4

1 C: Customer's inquiry

2 S: Statement of inability

3 C: Customer's insisting on the necessity of the item

4 S: Silence

5 C: Customer's inquiry about other stores

6 S: Providing information

$7 \quad$ Greeting

Speech sample 5

1 C: Customer's inquiry

2 S: Statement of inability

3 Apology

4 C: Customer's insisting on the necessity of the item

5 S: Statement of inability

6 C: Customer's inquiry about other stores

7 S: Providing information + Modal

Speech sample 6

1 C: Customer's inquiry

2 S: Statement of inability

3 C: Customer's insisting on the necessity of the item

4 S: Statement of inability

5 C: Customer's inquiry about other stores

6 S: Statement of inability

Speech sample 7

1 C: Customer's inquiry

2 S: Statement of inability + Repetition of question

3 C: Customer's insisting on the necessity of the item

4 S: Statement of inability

5 C: Customer's inquiry about other stores

6 S: Statement of inability

Speech sample 8

1 C: Customer's inquiry 
2 S: Statement of inability

3 C: Customer's insisting on the necessity of the item

4 S: Statement of inability

5 C: Customer's inquiry about other stores

6 S: Providing information

Speech sample 9

1 C: Customer's inquiry

2 S: Statement of inability

3 C: Customer's insisting on the necessity of the item

4 S: Statement of inability

5 C: Customer's inquiry about other stores

6 S: Statement of inability

Speech sample 10

1 C: Customer's inquiry

2 S: Repetition of question

3 Statement of inability

4 Providing information 


\section{Appendix B}

Transcript of role-play coded by semantic formulas

C: Customer S: Sales clerk

\section{In Japan}

Role-play 1

1 C: Alerter

Customer's inquiry

2 S: Apology

Statement of inability

3 C: Customer's insisting on the necessity of the item

4 S: Cajoler

5 Providing information

6 Modal

7 Suggestion

8 C: Response

9 S: Apology

10 C: Gratitude

Role-play 2

1 C: Alerter

2 S: Response

3 C: Customer's inquiry

4 S: Statement of inability

5 C: Customer's insisting on the necessity of the item

6 S: Alerter

7 Statement of inability

8 Providing information

9 C: Response

10 Customer's inquiry about other stores

11 S: Response

12 Providing information

13 C: Customer's inquiry about other stores

14 S: Response

15 Providing information

16 C: Gratitude

Role-play 3

1 C: Alerter

2 S: Repetition of Question 
3 C: Customer's inquiry

4 S: Negative marker

5 Statement of inability

6 Apology

7 C: Customer's insisting on the necessity of the item

8 S: Avoidance

9 Providing the information about other stores

10 C: Response

11 S: Response

12 S: Gratitude

$13 \mathrm{C}$ : Response
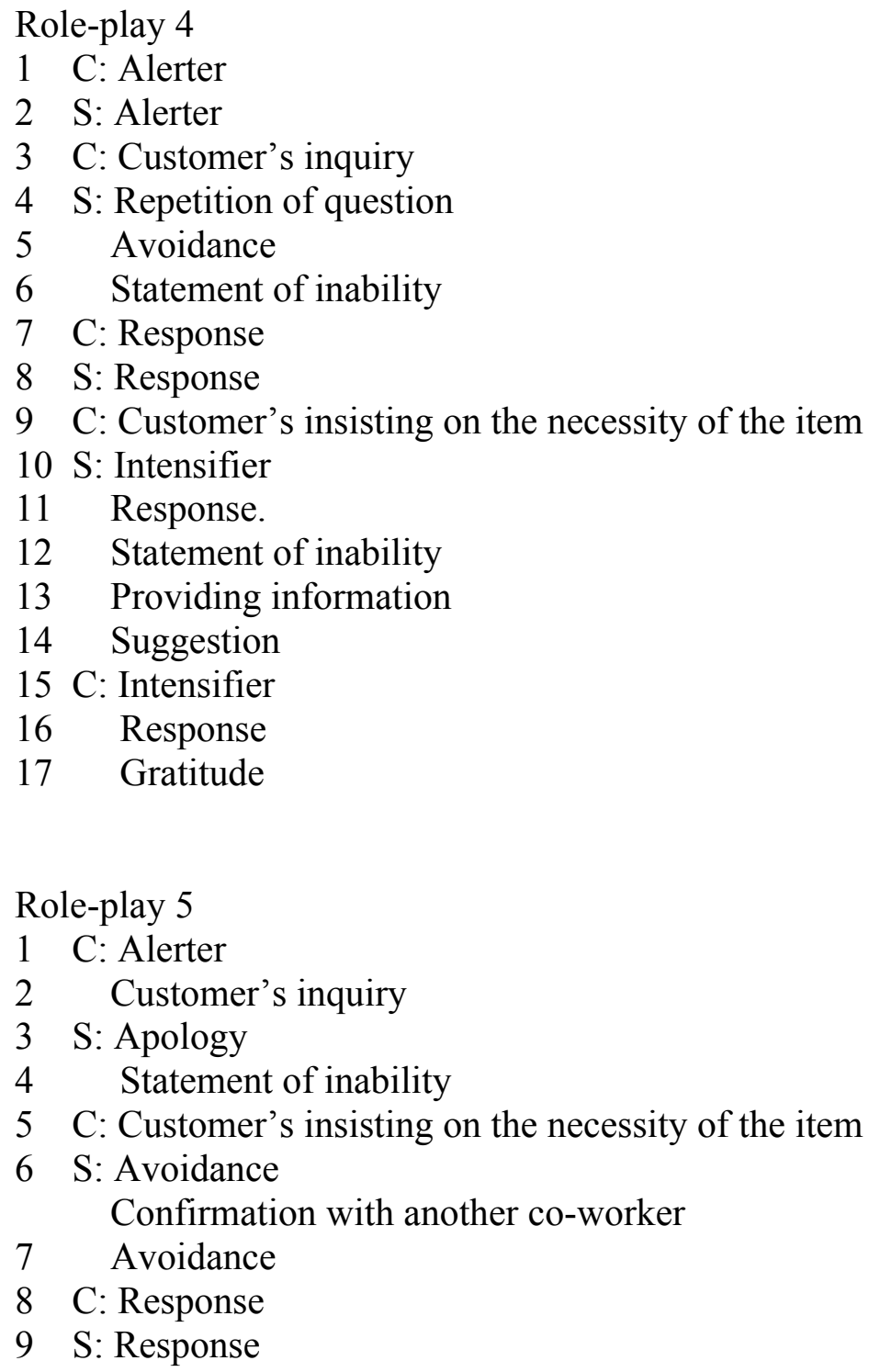
Role-play 6

1 C: Alerter

2 S: Response

3 C: Customer's inquiry

4 S: Apology

5 Statement of inability

6 Apology

7 C: Customer's insisting on the necessity of the item

8 S: Apology

9 Statement of inability

$10 \mathrm{C}$ : Customer's inquiry about other stores

$11 \mathrm{~S}$ : Avoidance

12 Intensifier

13 Cajoler

14 Providing information

15 Intensifier

16 Modal

17 C: Gratitude

\title{
In the U.S.
}

\author{
Role-play 1 \\ 1 C: Alerter \\ 2 S: Greeting \\ 3 C: Customer's inquiry \\ 4 S: Repetition of question \\ $5 \quad$ Negative marker \\ 6 Statement of inability \\ 7 Intensifier \\ 8 Apology \\ 9 C: Customer's insisting on the necessity of the item \\ $10 \mathrm{~S}$ : Repetition of question \\ 11 Negative marker \\ 12 Negative marker \\ 13 Modal \\ 14 Suggestion \\ 15 Negative marker \\ 16 Avoidance \\ 17 Providing information \\ 18 Modal \\ 19 C: Customer's inquiry about other stores \\ 20 S: Providing information \\ 21 Modal
}


22 Providing information

23 Intensifier

24 C: Customer's inquiry about other stores

25 S: Negative marker

26 Negative marker

27 Avoidance

28 Intensifier

29 Negative marker

30 Suggestion

31 Intensifier

32 C: Gratitude

Role-play 2

1 C: Alerter

2 S: Alerter

3 C: Response

4 Customer's inquiry

5 S: Intensifier

6 Apology

7 Statement of inability

8 C: Intensifier

9 Customer's insisting on the necessity of the item

$10 \mathrm{~S}$ : Negative marker

Sales clerk's inquiry

$11 \mathrm{C}$ : Response

12 S: Sales clerk's inquiry

13 C: Response

14 S: Providing information

$15 \mathrm{C}$ : Response

$16 \mathrm{~S}$ : Providing information

$17 \mathrm{C}$ : Gratitude

Role-play 3

1 C: Alerter

2 S: Alerter

3 C: Customer's inquiry

4 S: Apology

5 Statement of inability

6 C: Negative marker

7 Customer's insisting on the necessity of the item

8 S: Negative marker

9 Intensifier 
10 Statement of inability

11 Providing information

$12 \mathrm{C}$ : Response

Gratitude

13 S: Response

Role-play 4

1 C: Alerter

2 S: Greeting

3 C: Customer's inquiry

4 S: Intensifier

5 Statement of inability

6 Intensifier

7 C: Customer's insisting on the necessity of the item

8 S: Intensifier

9 Negative marker

10 Intensifier

11 Statement of inability

12 Intensifier

13 Providing information

14 Intensifier

15 C: Customer's inquiry about other stores

$16 \mathrm{~S}$ : Negative marker

17 Intensifier

18 Intensifier

19 Suggestion

20 Modal

21 C: Gratitude

22 S: Response

Role-play 5

1 C: Alerter

2 S: Alerter

3 C: Response

4 Customer's inquiry

5 S: Negative marker

6 Intensifier

7 Statement of inability

8 Sales clerk's inquiry

9 C: Customer's insisting on the necessity of the item

10 S: Intensifier

11 Statement of inability 
12 Providing information

13 Modal

14 Avoidance

15 C: Customer's inquiry about other stores

$16 \mathrm{~S}$ : Providing information

17 C: Gratitude

18 S: Response

\author{
Role-play 6 \\ 1 C: Alerter \\ 2 S: Response \\ 3 C: Customer' s inquiry \\ 4 S: Apology \\ 5 Statement of inability \\ 6 C: Customer's insisting on the necessity of the item \\ 7 S: Negative marker \\ 8 Apology \\ 9 Providing alternative items \\ $10 \mathrm{C}$ : Customer's insisting the necessity of the item \\ 11 S: Providing information \\ $12 \mathrm{C}$ : Customer's inquiry about other stores \\ 13 S: Negative marker \\ 14 Intensifier \\ 15 Negative marker \\ 16 Providing information \\ 17 C: Gratitude \\ 18 S: Response \\ 19 Gratitude
}




\section{Appendix C}

\section{Transcript of role-play}

C: Customer S: Sales clerk

\section{In Japan}

\section{Role-play 1}

1 C: Anoo, suimasen.

2 S: Hai. Irassyaimase.

3 C: Buruu chiizu arimasuka?

4 S: Buruu chiizu, cyotto uchino misedewa toriatukatte naindesuyo.

5 C: Soudesuka.

6 S: Hai.

7 C: Anoo. Kyoo Cyotto dooshitemo irundesuyonee.

8 S: Aa, soodesuka. Uchi no mise dewa atsukattenaindesukedo, tonari no, ano, anomise deshitara oitearukato omoimasunode, douzo ittemitekudasai.

9 C: A, soodesuka, wakarimashita. Arigatoogozaimasu.

\section{Role-play 2}

1 C: Ano, suimasen.

2 S: Hai.

3 C: Kochirani bruuchiizu arimasuka?

4 S: A, suimasen. Oitenaidesu.

5 C: Ano, kyoo cyotto dooshitemo irundesuyone.

6 S: A, soodesuka. Aa, bruu chiizu wa oitenaidesu. Hokano chiizunara arundesukedo.

7 C: Aa, soodesuka. Konohen ni dokoka oitesoonatokoro arimasuka?

8 S: Aa, arimasu. Aruite gofun kuraini.

9 C: A, soodesuka. Sugu wakarimasu? Kokokara suguni.

10 S: Soodesune. Dete, migini magatte massuguittara mitsukarimasu.

$11 \mathrm{C}$ : Wakarimashita. Arigatoogozaimasu.

\section{Role-play 3}

1 C: Ano, suimasen.

2 S: Hai.

3 C: Kochira ni bruuchiizu oitemasuka?

4 S: buruuchiizu, cyottooitenaindesuyone. Moushiwakearimasen.

5 C: A, soodesuka. Soshitara cytto, konochikakuni suupaa arunde sochira atatte moraemasuka?

6 S: Wakarimashita.

7 C: Hai.

8 S: Arigatoogozaimasu. 
9 C: Hai.

Role-play 4

1 C: Suimasen. Kochirani buruuchiizu oitemasuka.

2 S: Suimasen. Touten niwa bruuchiizu oitemasen.

3 C: A, ano, kyoo dooshitemo irundesuyone.

4 S: A, aa soodesuka. Ano sangentonarini suupaa ga gozaimasunode moshikashitara Sochirani oitearukamoshiremasennode cyotto sochirade otazuneitadakemasuka?

5 C: A, hai, wakarimashita. Ittemimasu.

6 S: Hai, mooshiwake gozaimasen.

7 C: Arigatoogozaimashita.

8 S: Hai.

Role-play 5

1 C: Ano, suimasen. Kochirani buruuchiizu oitemasuka?

2 C: Mooshiwakegozaimasen. Toutendewa buruuchiizuwa atukatte orimasen.

3 S: Aa, soodesuka. Ano, kyoo cyotto dooshitemo irundesukedo.

4 C: Hai. Soredeshitara cyotto uenomononi hoka no shiten tokade atukatteirukadouka cyotto kakuninshitekimasunode, cyotto omachikudasai.

5 S: Hai, suimasen. Onegaishimasu.

6 C: Haai.

Role-play 6

1 C: Ano, suimasen.

2 S: Hai.

3 C: Kochirani buruuchiizu oitemasuka?

4 S: Aa, mooshiwake gozaimasen. Kochiranohoodesune. Bruuchiizuwa oitemasennode, Mooshiwake gozaimasen.

5 C: A, soodesuka. Ano, kyoo dooshitemo reshipi ni irundesukedonee.

6 S: A, soodesuka. Mooshiwake gozaimasenga, kochiradeha

toriatukattegozaimasennode, Mooshiwake gozaimasen.

7 C: A, soodesuka. Jyaa, konohenni dokoka uttesounatokoroarimasuka.

8 S: Aa, soo, chikakuno suupaamaaketto deshitara moshikashitara atsukatteirukamo Shiremasennode, moshiyokattara sochiranohooni itteitadaketara to omoimasu.

9 C: Wakarimashita. Arigatoogozaimashita. Suimasen. 


\section{In the U.S.}

Role-play 1

1 C: Hi.

2 S: Hi.

3 C: Do you have blue cheese here?

4 S: Blue cheese...um, we don't actually sorry

5 C: Um, actually I really need that for my recipe tonight.

6 S: You do. Um, let's see you might try somewhere, let's see I don't know all much about blue cheese myself, but I imagine you could find it in the department store, grocery store that sells more gourmet items, maybe health food store something like that.

7 C: Um, is there any such grocery store around here?

8 S: Trader Joe's might, might have some. There is Trader Joe's definitely in town near by.

9 C: Um, where is it?

10 S: Um, um I can't recall address exactly, um, let me get some, someone over here who knows, I'm sure someone does, just one second.

$11 \mathrm{C}$ : Ok, thank you very much.

Role-play 2

$1 \mathrm{C}: \mathrm{Hi}$.

2 S: Hi, how are you today.

3 C: Good, thank you. Do you have blue cheese here?

4 S: Oh, I'm sorry. We don't sell blue cheese.

$5 \mathrm{C}$ : Oh, really, but I really need some for my recipe tonight

6 S: Um, how much do you need?

7 C: Um, a lot.

8 S: A lot. Have you check a grocery store?

9 C: No, really.

$10 \mathrm{~S}: \mathrm{OK}$. Here is the grocery store down the street, two brooks down.

$11 \mathrm{C}: \mathrm{OK}$.

12 S: If you go there, and go to the Deli, they should have blue cheese for ya.

$13 \mathrm{C}$ : OK, thank you very much.

Role-play 3

$1 \mathrm{C}: \mathrm{Hi}$.

2 S: Hi.

3 C: I have a question for you. Do you carry blue cheese here?

4 S: I'm sorry we don't have blue cheese.

5 C: Um, but I really need some for my recipe tonight....

6 S: Um, unfortunately we don't carry it. But, I think Safeway down the street might 
have.

7 C: OK.

8 S: Some blue cheese.

9 C: OK, I'll try that. Thank you.

$10 \mathrm{~S}$ : No problem.

Role-play 4

$1 \mathrm{C}: \mathrm{Hi}$.

2 S: Hi.

3 C: Do you carry blue cheese here?

4 S: Unfortunately, we do not carry blue cheese actually.

5 C: Oh really? But I really need one for my recipe tonight.

6 S: Oh, well, um unfortunately even though our store doesn't carry blue cheese, but maybe there other stores around this area but I'm not quite sure.

7 C: OK. Do you know there is other store around here?

8 S: Um, possibly, but I myself am not exactly sure so you might have to check.

9 C: OK, thank you very much.

$10 \mathrm{~S}$ : Yep.

Role-play 5

$1 \mathrm{C}: \mathrm{Hi}$.

2 S: Hi. How are you today?

3 C: Fine, thank you. Do you carry blue cheese here?

4 S: Um, actually we don't. Is there something else I can help you out to find?

5 C: Um, no, but I really need some for my recipe tonight. But you don't carry blue cheese here, right?

6 S: Unfortunately we don't, but I think there is another store around here, they might carry it, but I don't know.

$7 \mathrm{C}$ : Is there any other store around here? And do you know how to get there?

8 S: Yeah, I think Fred Meyers up this street had it, so if you go out, take a right, and it's around the corner.

9 C: OK. Thank you very much. I'll try that.

$10 \mathrm{~S}$ : No problem.

Role-play 6

$1 \mathrm{C}: \mathrm{Hi}$.

$2 \mathrm{~S}: \mathrm{Hi}$.

3 C: Do you carry blue cheese here?

4 S: I'm sorry. We don't have any here.

5 C: Oh, really. But I really need one for my recipe tonight.

6 S: Um, I'm sorry but we have some other types of cheese that might help you. 
7 C: OK. But I really need blue cheese, um...

$8 \mathrm{~S}$ : There is some other store in the area that carries blue cheese or there is substitute to use.

9 C: OK. Do you know exactly where that is?

$10 \mathrm{~S}$ : Um, maybe, um, maybe five minutes walking distance from here. There is another store you can find blue cheese.

$11 \mathrm{C}$ : OK. Thank you very much.

12 S: You're welcome. Thank you. 


\section{Appendix D}

Analysis of face-threatening acts in natural speech samples from convenience stores

C: Customer, S: Sales clerk

\section{In Japan}

Speech sample 1

Customer's inquiry

(Eliciting an FTA: S violates C's negative face, and S's positive face. )

Negative marker (S violates C's negative face, and S loses S's positive face)

Providing alternative items

(C loses C's negative face, $\mathrm{S}$ compensates for violation of C's negative face, $\underline{\text { S minimizes loosing S's positive face, })}$

Customer's insisting the necessity of the item

(Eliciting an FTA: S violates C's negative face, and S's positive face. )

Providing Information

(C loses C's negative face, $\mathrm{S}$ compensates for violation of C's negative face)

Gratitude (S mitigate S's FTA)

Speech sample 2

Customer's inquiry

(Eliciting an FTA: S violates C's negative face, and S's positive face. )

Repetition of question (S maintains S's positive face)

Statement of inability (S violates C's negative face, and S loses S's positive face)

Customer's insisting the necessity of the item

(Eliciting an FTA: S violates C's negative face, and S's positive face. )

Confirmation with another co-worker (S maintains S's positive face)

Statement of inability by co-worker

(S violates C's negative face, and S loses S's positive face)

Customer's inquiry about other stores

(Eliciting an FTA: S violates C's negative face, and S's positive face. ) 
Providing information + Modal

(S maintains S's positive face, C maintains C's negative face.)

Gratitude (S maintains S's positive face.)

Speech sample 3

Customer's inquiry

(Eliciting an FTA: S violates C's negative face, and S's positive face. )

Repetition of question (S maintains S's positive face)

Negative marker $\quad$ (S violates C's negative face, and S lose S's positive face)

Avoidance (S violates C's negative face, and S lose S's positive face)

Providing alternative item

(C loses C's negative face, $\mathrm{S}$ compensates for violation of C's negative face,

$\underline{\text { S minimizes loosing S's positive face, }}$

Customer's insisting the necessity of the item

(Eliciting an FTA: S violates C's negative face, and S's positive face. )

Silence (S avoids an FTA)

Customer's inquiry about other stores

(Eliciting an FTA: S violates C's negative face, and S's positive face. )

Suggestion (S compensate for violation of C's negative face)

Gratitude (S maintains S's positive face.)

Speech sample 4

Customer's inquiry

(Eliciting an FTA: S violates C's negative face, and S's positive face. )

Repetition of question (S maintains S's positive face)

Negative marker (S violates C's negative face, and S loses S's positive face)

Indicating alternative items (S compensates for violation of C's negative face)

Customer's insisting the necessity of the item

(Eliciting an FTA: S violates C's negative face, and S's positive face.)

Providing information + encouragement (Ippai arimasu yo.) 
(C loses C's negative face, $\mathrm{S}$ compensates for violation of C's negative face)

+ ( S mitigates S's violation of C's negative face)

Gratitude (S maintains S's positive face.)

Speech sample 5

Customer's inquiry

(Eliciting an FTA: S violates C's negative face, and S's positive face.)

Providing alternative items (check out the shelf)

(C loses C's negative face, $\mathrm{S}$ compensates for violation of C's negative face)

Customer's insisting the necessity of the item

(Eliciting an FTA: S violates C's negative face, and S's positive face.)

Repetition of question (blue cheese desu ka...) (S maintains S's positive face)

Providing information + Modal

(C loses C's negative face, $\mathrm{S}$ compensates for violation of C's negative face)

Apology (S maintains S's positive face.)

Gratitude (S maintains S's positive face.)

Speech sample 6

Customer's inquiry

(Eliciting an FTA: S violates C's negative face, and S's positive face.)

Repetition of question

(S violates C's negative face, and S lose S's positive face)

Providing alternative items

(C loses C's negative face, $\mathrm{S}$ compensates for violation of C's negative face, $\underline{\text { S minimizes loosing S's positive face, })}$

Statement of inability (S violates C's negative face, and S loses S's positive face)

Customer's insisting the necessity of the item

(Eliciting an FTA: S violates C's negative face, and S's positive face. )

Providing information + Modal

(C loses C's negative face, $\mathrm{S}$ compensates for violation of C's negative face) 
Speech sample 7

Customer's inquiry

(Eliciting an FTA: S violates C's negative face, and S's positive face.)

Repetition of question (S maintains S' s positive face.)

Confirm with another co-worker ( S maintains S' s positive face.)

Statement of inability (S violates C's negative face, and S loses S's positive face)

Customer's insisting the necessity of the item

(Eliciting an FTA: S violates C's negative face, and S's positive face.)

Silence + Avoidance (S violates C's negative face, and S loses S's positive face)

Speech sample 8

Customer's inquiry

(Eliciting an FTA: S violates C's negative face, and S's positive face.)

Repetition of question (S maintains S' s positive face.)

Negative marker (S violates C's negative face, and S loses S's positive face)

Customer's insisting the necessity of the item

(Eliciting an FTA: S violates C's negative face, and S's positive face.)

Silence (S violates C's negative face, and S loses S's positive face)

Customer's inquiry about other stores

(Eliciting an FTA: S violates C's negative face, and S's positive face.)

Providing information + Modal + Modal + Modal

(S maintains S's positive face, C maintains C's negative face.)

Speech sample 9

Customer's inquiry

(Eliciting an FTA: S violates C's negative face, and S's positive face.)

Avoidance (S violates C's negative face, and S lose S's positive face)

Statement of inability

(S violates C's negative face, and S loses S's positive face) 
Customer's insisting the necessity of the item

(Eliciting an FTA: S violates C's negative face, and S's positive face. )

Avoidance (S violates C's negative face, and S lose S's positive face)

Customer's inquiry about other stores

(Eliciting an FTA: S violates C's negative face, and S's positive face. )

Providing information (reluctantly)

(S maintains S's positive face, C maintains C's negative face.)

Speech sample 10

Customer's inquiry

(Eliciting an FTA: S violates C's negative face, and S's positive face. )

Avoidance (S violates C's negative face, and S lose S's positive face)

Statement of inability (S violates C's negative face, and S loses S's positive face)

Customer's insisting the necessity of the item

(Eliciting an FTA: S violates C's negative face, and S's positive face. )

Negative marker (S violates C's negative face, and S lose S's positive face)

Customer's inquiry about other stores

(Eliciting an FTA: S violates C's negative face, and S's positive face. )

Statement of inability (S violates C's negative face, and S loses S's positive face)

Apology (S maintains S's positive face.)

Speech sample 11

Customer's inquiry

(Eliciting an FTA: S violates C's negative face, and S's positive face. )

Repetition of question (S maintains S's positive face.)

Avoidance (S violates C's negative face, and S lose S's positive face)

Confirm with co-worker (S maintains S's positive face.)

Customer's insisting the necessity of the item

(Eliciting an FTA: S violates C's negative face, and S's positive face. )

Silence (S violates C's negative face, and S loses S's positive face) 
Customer's inquiry about other stores

(Eliciting an FTA: S violates C's negative face, and S's positive face. )

Providing information

(S maintains S's positive face, C maintains C's negative face.)

Gratitude (S maintains S's positive face.)

\section{In the U.S.}

Speech sample 1

Alerter (attention-getter)+ Alerter (Title)

Customer's inquiry

(Eliciting an FTA: S violates C's negative face, and S's positive face. )

Statement of inability (S violates C's negative face, and S loses S's positive face)

Customer's insisting the necessity of the item

(Eliciting an FTA: S violates C's negative face, and S's positive face. )

Confirm with another co-worker (S maintains S's positive face.)

Silence (S violates C's negative face, and S loses S's positive face)

Customer's inquiry about other stores

(Eliciting an FTA: C violates S's negative face)

Providing information

(S maintains S's positive face, C maintains C's negative face.)

Greeting (S maintains S's positive face.)

Speech sample 2

Customer's inquiry

(Eliciting an FTA: S violates C's negative face, and S's positive face. )

Statement of inability (S violates C's negative face, and S loses S's positive face.)

Customer's insisting the necessity of the item

(Eliciting an FTA: S violates C's negative face, and S's positive face. )

Providing information

$\underline{\text { (C loses C's negative face, } S \text { compensates for violation of C's negative face) }}$

Greeting (S maintains S's positive face.) 
Speech sample 3

Customer's inquiry

(Eliciting an FTA: S violates C's negative face, and S's positive face. )

Statement of inability (S violates C's negative face, and S loses S's positive face.)

Customer's insisting the necessity of the item

(Eliciting an FTA: S violates C's negative face, and S's positive face. )

Providing information

$\underline{(\mathrm{C} \text { loses } \mathrm{C} \text { 's negative face, } \mathrm{S} \text { compensates for violation of C's negative face) }}$

Speech sample 4

Customer's inquiry

(Eliciting an FTA: S violates C's negative face, and S's positive face. )

Statement of inability (S violates C's negative face, and S loses S's positive face.)

Customer's insisting the necessity of the item

(Eliciting an FTA: S violates C's negative face, and S's positive face. )

Silence (S violates C's negative face, and S loses S's positive face)

Customer's inquiry about other stores

(Eliciting an FTA: S violates C's negative face, and S's positive face. )

Providing information

(S maintains S's positive face, C maintains C's negative face.)

Greeting (S maintains S's positive face.)

Speech sample 5

Customer's inquiry

(Eliciting an FTA: S violates C's negative face, and S's positive face. )

Statement of inability (S violates C's negative face, and S loses S's positive face.)

Apology (S maintains S's positive face.)

Customer's insisting the necessity of the item

(Eliciting an FTA: S violates C's negative face, and S's positive face. ) 
Statement of inability (S violates C's negative face, and S loses S's positive face.)

Customer's inquiry about other stores

(Eliciting an FTA: S violates C's negative face, and S's positive face. )

Providing information + Modal

(S maintains S's positive face, C maintains C's negative face.)

Speech sample 6

Customer's inquiry

(Eliciting an FTA: S violates C's negative face, and S's positive face. )

Statement of inability (S violates C's negative face, and S loses S's positive face.)

Customer's insisting the necessity of the item

(Eliciting an FTA: S violates C's negative face, and S's positive face. )

Statement of inability (S violates C's negative face, and S loses S's positive face.)

Customer's inquiry about other stores

(Eliciting an FTA: S violates C's negative face, and S's positive face. )

Statement of inability (S violates C's negative face, and S loses S's positive face.)

Speech sample 7

Customer's inquiry

(Eliciting an FTA: S violates C's negative face, and S's positive face. )

Statement of inability + Repetition of question

(S violates C's negative face, and S loses S's positive face.) +

(S attempts to recover from losing S's positive face.)

Customer's insisting the necessity of the item

(Eliciting an FTA: S violates C's negative face, and S's positive face. )

Statement of inability (S violates C's negative face, and S loses S's positive face.)

Customer's inquiry about other stores

(Eliciting an FTA: S violates C's negative face, and S's positive face. )

Statement of inability (S violates C's negative face, and S loses S's positive face.) 
Speech sample 8

Customer's inquiry

(Eliciting an FTA: S violates C's negative face, and S's positive face. )

Statement of inability (S violates C's negative face, and S loses S's positive face.)

Customer's insisting the necessity of the item

(Eliciting an FTA: S violates C's negative face, and S's positive face. )

Statement of inability (S violates C's negative face, and S loses S's positive face.)

Customer's inquiry about other stores

(Eliciting an FTA: S violates C's negative face, and S's positive face. )

Providing information

(S maintains S's positive face, C maintains C's negative face.)

Speech sample 9

Customer's inquiry

(Eliciting an FTA: S violates C's negative face, and S's positive face. )

Statement of inability (S violates C's negative face, and S loses S's positive face.)

Customer's insisting the necessity of the item

(Eliciting an FTA: S violates C's negative face, and S's positive face. )

Statement of inability (S violates C's negative face, and S loses S's positive face.)

Customer's inquiry about other stores

(Eliciting an FTA: S violates C's negative face, and S's positive face. )

Statement of inability (S violates C's negative face, and S loses S's positive face.)

Speech sample10

Customer's inquiry

(Eliciting an FTA: S violates C's negative face, and S's positive face.)

Repetition of question (S maintains S's positive face.)

Statement of inability (S violates C's negative face, and S loses S's positive face.)

Providing information (S compensate for violation of C's negative face.) 


\section{Appendix E \\ Informed Consent (English)}

\section{Informed Consent Form}

Research Project: A study of the compensation of a face-threatening act in service encounters within Japan and the US

You are invited to participate in a research project, "A study of the compensation of a face threatening act in service encounters within Japan and the US" conducted by the researcher Miki Murakami, a graduate student of The Department of Foreign Languages and Literatures at Portland State University. This research is being conducted in partial fulfillment of the requirements for a master's degree under the supervision of Dr. Suwako Watanabe. The researcher hopes to discover how people compensate for their inability of meeting others needs/wants within service encounters by using different languages, and

to compare how each language behaviors are affected by their cultural norms such as politeness, between America and Japan. You have been selected as a possible participant

in this study because you are currently living in America, and you are not Japanese.

If you decide to participate, it will involve your participation in a role-play within a specific context that will be given. The role-play will be acted out between yourself and the researcher. This role-play will be recorded and last approximately 5 minutes. The role-play will be in your native language. I will accommodate your schedule by conducting the role-play where it is convenient for you, as long as the place is suitable for recording. You may feel uncomfortable answering some of the questions, but you can omit any questions you do not wish to answer. Moreover, you can always pause and stop your performance during the role-play whenever you wish.

You may feel that your participation might adversely affect your social activities or your self-image; however, it is very unlikely that your participation will negatively affect any of your social activities, and all information and speech data I obtain from you will not be shared with anyone else. You may not receive any direct benefit from participating in this study. However, your contribution facilitates others to increase their insight into the relationship between language and culture for certain purposes, i.e. compensation.

Any information that is obtained in connection with this study and that can be linked to your identity will be kept confidential. This information will be kept confidential by storing it in a safe place to which only the researcher will have access, and will never be used for any other purpose. When I report the findings from this study, it will be presented in an aggregate manner (i.e. as a group or by category). Therefore, although some general demographic information such as gender and age will be presented, there will be nothing that identifies you in the report. 
Your participation is voluntary. You do not have to take part in this study, and it will not affect your social activities or relationship with the researcher or Portland State University. You may withdraw from this study whenever you wish without any penalty.

If you have concerns or problems about your participation in this study or your rights as a research subject, please contact the Human Subjects Research Review Committee, Office of Research and Sponsored Projects, Portland State University, Portland OR 97207-0751, (503) 725-4288, email: hsrrc@lists.pdx.edu, if you have questions about this study itself, please contact Miki Murakami at (541)606-1506, email: murakamm@pdx.edu

Please understand that you may withdraw your consent at anytime without penalty, and that, by signing, you are not waiving any legal claims, rights, or remedies. The researcher should provide you with a copy of this form for your own records.

Signature

Date

Name (please print)

Email address 


\section{Appendix F \\ Informed Consent (Japanese)}

インタビュー同意書

相手の face（面目）をつぶしてしまうような行為に補償するための待遇表現に ついて

参加者の方へ

初めまして、ポートランド州立大学で日本語言語学を学んでいる村上美樹と申し ます。実生活における日本語使用の中で、「補償」とういう発話行為がどのよう に行われるのかについて研究しています。この研究は、日本語学部の Dr.

Suwako Watanabe の監督の下で、私の修士論文として行われています。この主な 目的には、会話の相手の面目を潰してしまうような行為を行ってしまった後に、 どのような言語活動によって「補償」するか、さらに、文化的規範の違いがその 発話過程にどのような影響を及ぼしているかを比較することで、その目的の為に、 日本在住の日本人と、アメリカ在住のアメリカ人の方に、参加をお願いしていま す。

参加に同意してくださった方には、指定された設定の中で、私とともにロールプ レイをしていただきます。ロールプレイは約 5 分程度を予定しており、録音させ ていただきます。ロールプレイは日本語で行われます。ロールプレイを録音させ ていただく日程、場所等は録音に適した場所である限り、参加者の方の都合に合 わさせていただきます。ロールプレイをしている最中に、続行したくない場合は いつでも中断することができますし、ロールプレイを終了することもできます。 この研究に参加することによって、ご自身の社会活動や、イメージに何らかの影 響が出るのではないかと不安に思われるかもしれませんが、その可能性は全くあ りません。この研究に参加することによって、皆さんに直接的利益は得られな いかもしれませんが、今後の日本語教育に少しでも貢献できる情報を得られるこ とは、今後の言語理解と文化の相互理解の発展において非常にありがたく、有意 義なことです。

この研究において得られた皆さんの個人情報や録音したロールプレイは研究終了 後も、安全な場所で保管され、他の人の目に触れることも、この研究以外に使わ れることはありません。たとえこの研究結果を外部で報告するようなことがあっ ても、集団として扱いますので、皆さんからいただいた情報を皆さん個人のもの であると確定することはできません。

この研究の参加、不参加は全くの自由です。いかなる選択をされても、皆さんの 社会活動に影響することはありません。いつでも皆さんの都合でこの研究への参 加をやめていただいて結構です。研究参加者としての権利に関してご質問等がご ざいましたら、お手数ですがこちらまでご連絡お願い致します。 
Human Subjects Research Review Committee, Office of Research and Sponsored Projects, Portland State University, Portland OR 97207-0751, (503) 725-4288, email: hsrrc@lists.pdx.edu この研究に関する質問は、村上までお願いいたします。 村上美樹（日本：076-275-811 9、アメリカ：541-60 6-150 6 )

ご協力の程、何卒よろしくお願い致します。

上記の説明をよく読み、同意される場合には、署名をお願い致します。皆さんは いつでもこの同意を撤回する権利を持ち、この署名をすることで法的権利が剥奪 されることはありません。その証明の為にも、皆さんもこの署名の複製を保持で きます。

署名

日付 


\section{Appendix G \\ Situation Card for oral role-play (English)}

Situation card for oral-play

You are working for a convenience store as a store clerk. One day, a customer comes in and asks you if your convenience store sells/carries blue cheese or not. Your convenience store does not sell/carry blue cheese. You are going to respond to the customer's inquiry, and develop the conversation as it goes.

Please take your time to imagine what you would say if you were in this situation in real life. Then, please let me know when you are ready to start role-playing. You will be a store clerk in a convenience store, and I, researcher, will be a customer. 


\section{Appendix $\mathbf{H}$ \\ Situation Card for oral role-play (Japanese)}

場面設定：コンビニエンスストア

あなたはコンビニエンスストアの店員です。お客さんが来店し、ブルーチーズを 置いているかどうか聞かれますが、あなたのお店にブルーチーズは置いていませ ん。あなたはそのことをお客さんに伝えます。その後はお客さんの発話に応じて、 会話を進めてください。

実際に自分がそのような状況になった時を想像してみてください。そしてどのよ うに発話するかをどうぞ十分に時間を取って考えてみてください。今からあなた はコンビニエンスストアの店員、私がお客さんの役でロールプレイをして頂きま すが、初めてもよろしければ教えて下さい。 